\title{
In the Tortuous Shadows of Ethnic Policies: Two \\ Case Studies of Chinese Cultural Heritage in \\ Indonesia and Malaysia
}

\author{
Gabriella Voss \\ iD https://orcid.org/0000-0002-4906-5871
}

\begin{abstract}
Concurrent with the inception of the nation states of Indonesia and Malaysia in the middle of the twentieth century, ethnic policies were put into practice to destroy the Chinese cultural heritage that had hitherto been regarded as a vital part of the region's heterogeneous cultural landscapes. Chinese language, organisations, and religious practices were banned, and architecture and artefacts with Chinese symbols or insignia either looted or destroyed. To what extent have these discriminatory agendas further influenced and shaped contemporary Chinese cultural heritage discourse? To answer this question this article starts with an introduction to the anti-Chinese agenda from Independence onwards, which is followed by two case studies from the field of cultural heritage: the organisation Boen Hian Tong in Semarang on Java in Indonesia, and the NGO Penang Heritage Trust in Malaysia. The research is based on fieldwork carried out in Indonesia and Malaysia in 2014-2015.
\end{abstract}

Keywords: Chinese descendants in South East Asia, ethnic policies, cultural heritage, qualitative research, Indonesia, Malaysia

Voss, Gabriella. 2021. "In the Tortuous Shadows of Ethnic Policies:

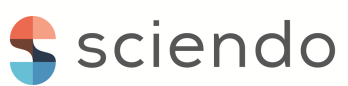

Two Case Studies of Chinese Cultural Heritage in Indonesia and Malaysia." Vienna Journal of East Asian Studies, 13, pp. 141-176. https://doi.org/10.2478/vjeas-2021-0005

Submitted: 21.12.2020, accepted: 25.01.2021

This work is licensed under the Creative Commons Attribution 4.0 International License. http://creativecommons.org/licenses/by/4.0/ 


\section{Introduction $^{1}$}

As Indonesia and Malaysia gained independence in the middle of the twentieth century, people of Chinese descent became increasingly targeted by different ethnic policies, ranging from cultural pluralism, acculturation, assimilation to even outright expulsion and murder. The forceful and involuntary alienation that followed these policies further identified them as "essential outsiders" (Chirot and Reid 1997). As a result, people of Chinese descent were often treated as a "disconnected analytical category" (Liu 2011: 15), instead of being regarded as an integral part of these new-born nation states. ${ }^{2}$

In the 1960s, the situation started to deteriorate. In the case of Indonesia, this was manifested in the calamities of 1965, when President Suharto's (1921-2008) war against Communism led to the death of more than one million people. Suspected to be supportive of Communism, many of these victims were of Chinese descent. In the aftermath of this human tragedy, Suharto's regime decided that the Chinese had to become "less Chinese" in order to make the South Asian state more "secure" with the argumentation that the People's Republic of China (PRC) would thus have less impact on their overseas communities. On top of this agenda was the destruction of the cultural pillars of Chinese ethnic organisations, language, and religion (Suryadinata 2001; 2005; 2013).

In the case of Malaysia, the political landscape changed after racial riots in 1969 as new claims were made in the name of Malay supremacy (ketuhanan Melayu). As the people of Chinese descent accounted for more than twenty per cent of the Malaysian population, the outcome was far less harrowing and invasive than in Indonesia, where these numbers are closer to two to three per cent.

The aim of this article is twofold: first, to briefly explain how various political agendas have influenced and changed the social, political, and cultural landscape for people of Chinese descent in Indonesia and Malaysia from the middle of the twentieth century onwards; ${ }^{3}$ second, to show how these different ethnic policies have had last-

\footnotetext{
${ }^{1}$ This article is a revised and abbreviated version of Szabó 2015.

2 Shamsul and Sity (2006: 134-135) argue that we should be wary of the difference between "state" and "nation state" as has already been proven by the trajectories of a variety of postcolonial countries. Singapore is a "state nation" where the state reinvents the needs of the nation according to the needs of the state, and Malaysia is an example of "states-without-nation" as it is made up of a twotier federation. The first tier is the Federation of Malaya with eleven provinces becoming independent in 1957, with the second being made up by the Federation of Malaysia, consisting of the previous mentioned Federation of Malaya plus the provinces of Sabah and Sarawak, which were declared independent in 1963. In this article I am willingly "sacrificing epistemological clarity" (ibid.: 134) through the definition of Malaysia as a nation state.

${ }^{3}$ I prefer to use the term "people of Chinese descent" instead of "overseas Chinese," which has for long been the English term, established in the era when the Chinese were predominantly regarded
} 
ing effects on Indonesian and Malaysian heritage discourse. The first part thus provides a contextualisation of these different ethnic policies, and the second part introduces two case studies based on fieldwork carried out in Semarang on Java in Indonesia (January to February 2014 and January 2015), and George Town in Malaysia (February and December 2014). ${ }^{4}$

\section{Ethnic Policies Targeting People of Chinese Descent in Southeast Asia}

The Chinese Indonesian sinologist Leo Suryadinata (b. 1940) concludes that the different policies directed towards people of Chinese descent in Southeast Asia are most probably reflecting the demographic structures of the different nation states (Suryadinata 2013: 275). If the percentage of people of Chinese descent is low, the "temptation" of the government to enforce assimilation policies tends to be rather strong. ${ }^{5}$ If the percentage is high, the assimilation will prove to be both problematic and unrealistic, and the governments will instead resort to either policies of accommodation or partial acculturation. ${ }^{6}$ Regardless of the chosen strategy, the Southeast Asian governments will make efforts to keep the population of Chinese descent small in number, either

as sojourners (Coppel 2013: 345). The denomination sojourner is further related to huáqiáo 华侨/ 華僑 (overseas Chinese) that first appeared in 1883, "implicitly implying a presumptuous jurisdiction of China over all ethnic Chinese outside of China based on a loose interpretation of descent" (Tan 2013: 17). Since 1978, however, huáqiáo has been restricted to "Chinese citizens living abroad, while the Chinese who have adopted the citizenship of the countries of their residence are referred to as haiwai huaren [i.e., hăiwài huárén 海外华人]” (Tan 2013: 2-3).

${ }^{4}$ Contrary to Semarang, there is a vast pool of data available in George Town, which means that the research process in Malaysia has not been focusing on interviews or on the gathering of data in situ to the same extent as in Indonesia.

${ }^{5}$ Assimilation is "the process of erasing the boundary between one group and another. There are two principal varieties of assimilation. Two or more groups may unite to form a new group, larger and different from any of the component parts. This we refer to as amalgamation [...] alternatively, one group may lose its identity by merging into another group, which retains identity. This we call incorporation" (Horowitz 1975: 115). When Suryadinata describes the situation in Southeast Asia, he refers to the latter variant of assimilation.

${ }^{6}$ Acculturation commonly refers to a dynamic process where the culture of a society (or group, such as an ethnic group) is modified and changed through the contact with another society (or group). However, acculturation could also be understood on an individual level and it is a one-way unidirectional process of change - contrary to assimilation, which constitutes a "give-and-take relationship." For a thorough discussion about the difference between assimilation and acculturation, see Teske and Nelson 1974. In my understanding, Suryadinata refers to acculturation as a less invasive, thus "weaker" form of assimilation. With accommodation, he refers to the development of different working arrangements, whereby the distinct identities of the groups are maintained, by which he decidedly "uses the term in a liberal way and do not exclude a certain degree of common national identity" (Suryadinata 2013: 288). 
by stopping Chinese immigration or through the "import" of other migrants from neighbouring countries.

\section{Policies Towards People of Chinese Descent in Indonesia}

Under Sukarno's presidency (1945-1967), the newly established PRC increasingly came to play a dominant role in Indonesia's nation building. Sukarno was utterly impressed by what he experienced during his visits to China: "I witnessed the realization of my ideals formulated since 1929 [...]. In the PRC I saw the practice of a guided democracy, and only this democracy with guidance can bring people into a new world, a truly just and prosperous new world" (cited in Liu 2011: 222). Sukarno admitted that he was greatly inspired by Sun Yat-sen (Sūn Yìxiān 孫逸仙/孙逸仙, 1866-1925), the founding father of the Republic of China, and that the Three People's Principles that Sun had developed (democracy, nationalism, and socialism) had become a great source of inspiration for the Indonesian concept of Pancasila. ${ }^{7}$

According to Liu (2011), during these early formative years of the Indonesian nation, the PRC became a contested metaphor: both positively (through its hardworking population, powerful administration, rapid economic growth, and an orderly social system) and negatively (as the citizens lacked both basic rights and religious freedom). Two things are noteworthy in this selective perception of the PRC:

1. The PRC was conceptually delinked from Communism; instead, it was seen as a showcase of a gigantic, profoundly nationalistic, and populist experiment.

2. The stronger the enthusiasm for the PRC as a nation grew, the stronger the disdain against the Chinese ethnic minority in Indonesia developed, thus the Chinese in the PRC and in Indonesia were seen as "brothers of different kinds" (Liu 2011: 168), with the Chinese Indonesians depicted as opportunists, lacking in loyalty towards the Indonesian nation.

Although the PRC was admired for its accomplishments, Indonesian policy makers were wary of Běijīng's increasing power, and the question of citizenship among the Chinese locals became a pressing issue. In a two-year period, between 1949 and 1951, Indonesian-born Chinese could choose their citizenship, with the status of wives and

\footnotetext{
${ }^{7}$ Pancasila (a Sanskrit derived term meaning the five principles) can be found in the preamble to the Indonesian constitution, promulgated on August 18, 1945, one day after the declaration of independence. It comprises the official philosophical ideas of the Indonesian state: 1. Belief in the divinity of God (Ketuhanan Yang Maha Esa). 2. Just and civilised humanity (Kemanusiaan Yang Adil dan Beradab). 3. The unity of Indonesia (Persatuan Indonesia). 4. Democracy guided by the inner wisdom in the unanimity arising out of deliberations among representatives (Kerakyatan Yang Dipimpin oleh Hikmat Kebijaksanaan, Dalam Permusyawaratan dan Perwakilan). 5. Social justice for all the people of Indonesia (Keadilan Sosial bagi seluruh Rakyat Indonesia).
} 
children following the father's choice (Willmott 1960). Due to the lack of any easy voluntary naturalisation process, the concept of jus sanguinis that the Qing Nationality Law had promulgated in 1909 was applied (Tan 2013: 7). ${ }^{8}$ In the educational sector, a standard national curriculum was imposed to limit the active usage of the Chinese language within the school system.

In the night of September 30, 1965, the situation exacerbated as six high-ranking generals from the Indonesian Army were assassinated, resulting in a wide-reaching extermination of alleged Communists, who, according to President Suharto, were the ones to blame. This mass murder was orchestrated by a massive propaganda machinery throughout the whole nation, with the aim to purge the entire Partai Komunis Indonesia (PKI), which at that time, with its three million members, was the largest nonruling Communist party in the world. ${ }^{9}$ These atrocities that vastly targeted the population of Chinese descent definitely altered the political landscape. The consequences of this incident played a pivotal role in the stigmatisation process of Chinese identity discourse in the following decades. ${ }^{10}$

Suharto's aspiration was the extermination of all Communists and an assimilation policy that severely affected the population of Chinese descent. Already in 1966, almost all Chinese schools had to close. There were no written laws on enforced namechanges for Chinese-sounding names, but different kinds of regulations were imposed making it virtually impossible to live in Indonesia using a Chinese-sounding name. This sanction caused severe damage to the traditional patriarchal Chinese family structure, where a name carries a deep function in a complex kinship system. The use of Chinese language was restricted in public places, and independent Chinese press became prohibited.

In June 1967, "The Basic Policy for the Solution of the Chinese Problem" was promulgated, followed by another one on Chinese religion, beliefs, and customs. "All forms of cultural affinity based on the country of origin should be removed, in order to give all elements of culture in Indonesia the opportunity to develop according to the Pancasila" (Coppel 2002: 115). This "Chinese problem" (masalah Cina), a top priority one on the assimilationist agenda, also included a financial redistribution programme, with the intention to concurrently assure the reduction of Chinese capital

\footnotetext{
${ }^{8}$ Jus sanguinis (Latin for "right of blood") refers to citizenship not determined by the place of birth but by the citizenship of one or both parents, which is the opposite of jus soli (Latin for "right of the soil"): citizenship determined through location of birth. Due to the application of jus sanguinis, some Chinese individuals became stateless in these years, a status which was passed on to their children and has lasted until the twenty-first century.

${ }^{9}$ In Bali up to 80,000 people were murdered within two weeks, and in Java and Sumatra the killings were extended and lasted for three months.

${ }^{10}$ See Joshua Oppenheimer's highly acclaimed films "The Act of Killing" (2012) and "The Look of Silence" (2014) for a further understanding of the magnitude of this tragic event and how it still influences all levels of Indonesian society.
} 
while curtailing cultural expression. The intentions of Badan Permusjawaratan Kewarganegaraan Indonesia (BAPERKI), a Chinese mass organisation proposing integration based on the idea that the Chinese Indonesians were just another minority among a wide range of national minorities, were not accepted and the organisation was banned. The aim was to "depoliticize the Chinese community" (Suryadinata 2001: 505) and to direct their activities away from culture and politics, channelling them instead into the domain of economy. Cultural practices, such as dragon performances or lion dance, were banned in the public and had to be carried out within individual households. The fear and insecurity arising from these new instructions also altered various practices around the klenteng (Chinese temple).

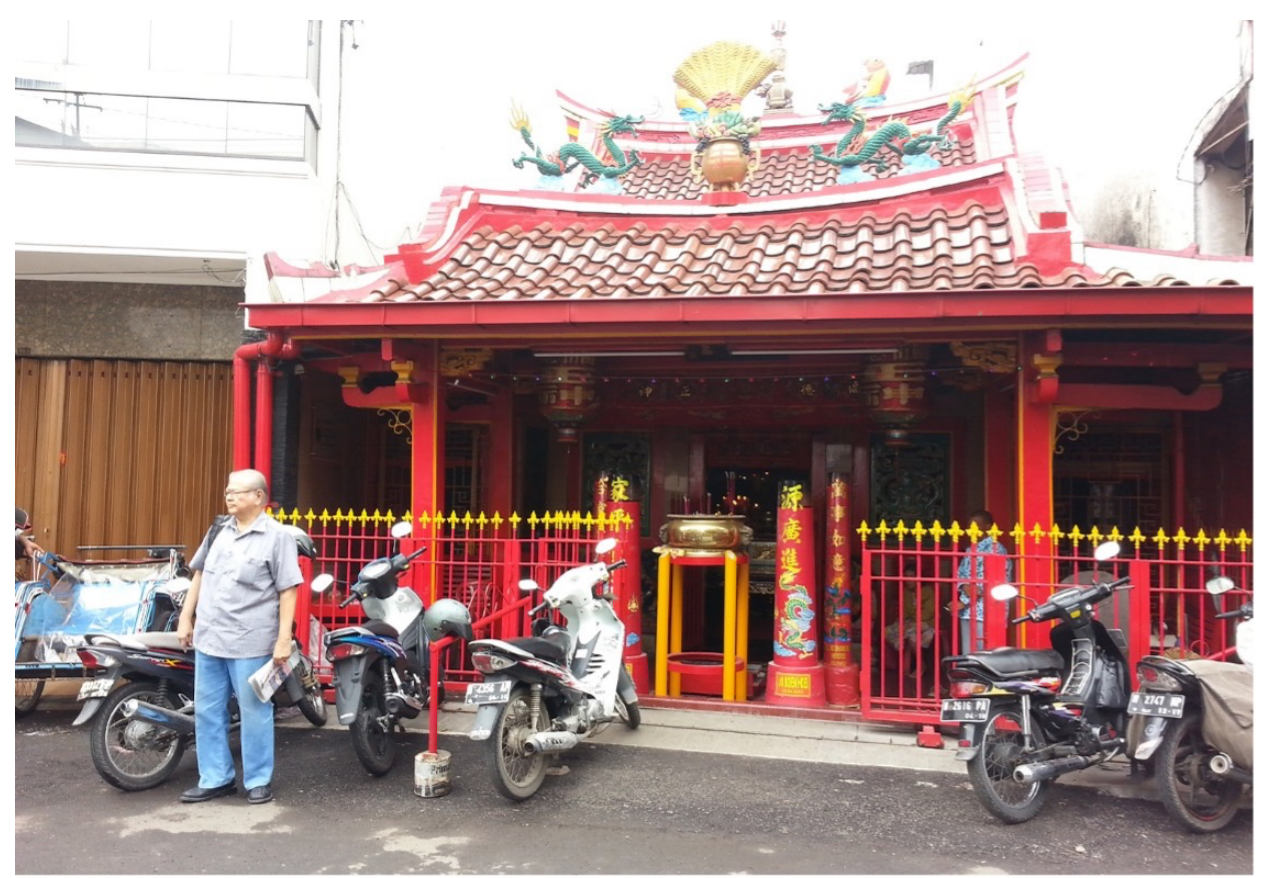

Klenteng in Pecinan, January 2015. (Photo: Gabriella Voss)

Being of crucial importance in its social role as a place for meetings as well as collective or individual worship, the klenteng had been a hub for Chinese communities ever since its formation. ${ }^{11}$ Questions were also officially posed as to what extent it

\footnotetext{
${ }^{11}$ In the wake of the implementation of these new instructions, people were afraid to continue the rite of placing commemorative tablets of their deceased family members at the altars of the klenteng, as this could put the tablets at risk. It also revealed that the family was still under "Chinese cultural influence." The consequence thereof was that different ceremonies related to the klenteng often fell into neglect.
} 
could be acceptable to venerate ancestral ashes (Alabahin 2005: 128). Confucianism lost its state-recognition as a religion and followers were encouraged to register themselves on the mandatory residential identity card as Buddhists, or opt for one of the other four religions. Confucianism and Daoism, pertaining to sam khaw (Chinese: sānjiào 三教, the "Three Teachings"), were also placed under Buddhism according to the Ministry of Religion in 1967. Symbols also had to be "de-Sinicised" as all Chinese insignia had to be covered or removed. As religious registration was mandatory, the propensity of the Chinese Indonesians had been to affiliate with either Buddhism or Christianity; belonging to a Christian community could possibly enhance the feeling of being protected, as these communities were widely accepted among the indigenous Indonesians. $^{12}$

In May 1998, large-scale turmoil including raping, torturing, and killing, especially directed towards women of Chinese descent, took place in various Indonesian cities. ${ }^{13}$ The final report of the Joint Fact Finding Team, an investigative group put together by the Indonesian government, clearly proves the "willingness of state officials at both local and national levels to incite violence against ethnic Chinese as a diversionary strategy aimed at stabilizing the regime nationally" (Panggabean and Smith 2011:231). During the protest that had originally started as a mass mobilisation against President Suharto and the New Order Regime, the army was successful in its frame-shifting strategy to redirect the anger from the intentional target towards the Chinese Indonesians. The Human Rights Watch has also exposed evidence of meetings between preman (criminals) and army officials to plan anti-Chinese violence in Java earlier that year (ibid.). ${ }^{14}$

During the presidency of Abdurrahman Wahid (also referred to as Gus Dur; 19402009) between 1999 and 2001, things started to change for the better. Advocating the principles of minority rights and a more tolerant pluralistic Indonesian society, he cancelled the Presidential Instruction 14/1967 referred to above as the "Chinese Problem," which had prohibited Chinese religion, beliefs, and customs in the public space. Although not in office in 2002, he can also be regarded as the protagonist behind the

12 In 1976 there were four million Protestants in Indonesia, of whom at least 330,000 were Chinese, equalling to 10.6 per cent of all Chinese, and 15.8 per cent of the Peranakans (Italiaander 1976: 185). During the colonial era, Christianity sought identification with the elite, while after independence it meant identification with a part of the indigenous population and acceptance within the community, which became more important after 1965 (ibid.: 185-190).

${ }^{13}$ It is possible that the intention of the riots was to create a necessary amount of instability, which would then allow for the declaration of martial law. Another explanation suggests internal strife within the military, and the third explanation is suggesting that the intent was "to terrorize the Chinese community into leaving Indonesia forever" (Suryadinata 2001: 507).

${ }^{14}$ Immigration statistics show that more than 150,000 people fled Indonesia via airports and seaports in Sumatra, Bali, and Java between May 14-18, 1998, and, according to a Javanese business research report, as many as 110,000 Chinese families left Jakarta during these days alone (Suryadinata 2001: 508). 
decision that Imlek (Indonesian Chinese New Year) should become a national holiday from that year onwards (Alkatiri, Irmayanti, and Waworuntu 2015). For his deep engagement and empathy with Indonesian Chinese, Gus Dur has often been called "Bapak Tionghoa," literally meaning "the father of all Chinese."

\section{Policies Towards People of Chinese Descent in Malaysia}

The Federation of Malaysia came into existence in 1963. The new Constitution of 1957 stated that "Chinese residing in the Federation on Independence Day may, on satisfying an eight years' residence requirement, register as Malayan citizens, while all persons born in the Federation subsequent to independence are automatically citizens" (Skinner 1959: 143). It is striking, at this point, that the generous concept of jus soli as citizenship policy was applied, which granted both the Indians and the Chinese on Malayan soil immediate rights as nationals: "As Independence approached, the Malay political leaders showed a generosity in accommodating the newly settled communities, granting them citizenship on flexible terms - changing a Malay nation into a multi-ethnic and multi-religious modern nation almost overnight" (Muzaffar 2002: 319). According to Muzaffar, this inclusive and tolerant approach towards different ethnic groups and religions stretches back to the Malay-Muslim polity prior to British colonisation. ${ }^{15}$ These policies inevitably forced a new reality upon the Malay majority: from now on they were merely one community among others. To be certain that the Malay would remain the dominant ethnic group within the new nation state, the predominantly Chinese state of Singapore was given autonomy and granted complete independence on August 7, $1965 .^{16}$

Concurrently with the new conditions regarding citizenship, a change within the Chinese language media was notable. In the years prior to independence, the Chinese newspapers published in Malaya had called China their "homeland" and focused to a large extent on Chinese news. In 1957, this was changing, marking a decisive twist within the framing of the Chinese Malayan identity.

From now on, we must make a clear distinction between 'our country' and China [...] our national founding father is no longer Dr. Sun Yat-sen, but Prime Minister Tengku Abdul Rahman [...]. Our "national portrait" is no longer a Chinese picture scroll, but rather a batic sarong work of art [...]. The character for "country" is not the "guo" in Zhongguo; it is the 'Federation' of Malaya (Essay in Nanyang Siang Pau, 7 October 1957, cited in Hara 2003: 44).

An important issue on the agenda was the new language policy. In 1950, both the Kuomintang (Guómíndăng 中國國民黨) and the Communists had been engaged in

\footnotetext{
15 The Portuguese held Malacca from 1511 to 1641 , followed by the Dutch, who lost the control to the British in 1824 (see Purcell 1965: 24-26).

${ }^{16}$ This is certainly not the only reason for Singaporean independence; however, it is important to highlight this fact.
} 
fostering Chinese nationalism, ${ }^{17}$ but they were pushed back by the British, who tightened the regulations in order to control leftist elements and make the school curriculum more Malayan (Hara 2003: 12, 28).

In 1961, the Education Act stipulated one clear criterion: governmental subsidies for Malay primary schools only. All secondary schools were also obliged to follow the Malay curriculum. ${ }^{18}$ In 1969, all national schools had to use Malay, but a large number of Chinese secondary students chose to attend private schools (Suryadinata 2013: 284). Two distinct pressure groups, the Dǒngzhǒng 董总 and the Jiàzhǒng 教 总, ${ }^{19}$ fought for Chinese instruction at schools, and "the debate over education policy and the future of Chinese schools became part of a larger discourse on the status and rights of the Chinese within the Malayan nation. This took the Chinese education issue into the centre of Malayan politics" (Collins 2006: 302).

Three days after the federal elections, held on May 10, 1969, racial riots broke out. The funeral procession of a young Chinese man, allegedly Communist and certainly killed by the police, took place one day prior to the elections and 10,000 people came together to attend the ceremony, which eventually turned into a large demonstration. The struggle about language and education was a concern among all communities in the Malaysian society, and extensive tension spread during the following days resulting in the declaration of a State of Emergency on May 14, after 196 persons were found dead and 6,000 houses destroyed. The Malays were infuriated that the concept of "Malay supremacy" was being challenged (Berman 2011: 6).

General distrust spread from all sides while the government tried to control ethnic animosity through the press (Watson Andaya and Andaya 2001: 298-299). The Government tried to appease the displeased bumiputera Malays (literally "sons of the soil"; native Malays) through the New Economic Policy (NEP) and the National Culture Policy (NCP) that where both implemented in $1971 .{ }^{20}$ NEP and NCP intended to strengthen the position of the bumiputeras in different spheres of society, where civil service came to play an important role as heavily dominated by the Malay (Chin 2011:

\footnotetext{
${ }^{17}$ As the nationalist party Kuomintang came into power in China in 1927, all Chinese of Han origin were regarded as citizens of the country regardless of their other national status. This policy led to frictions with the local governments and was eventually harmful to the Chinese, as it made their loyalty towards the country of residence questionable.

${ }_{18}$ Out of seventy Chinese schools, fifty-four accepted the new constraints of the Educational Act.

${ }^{19}$ Jiàzhóng represents the vernacular school teachers, founded in 1951, and Dóngzhóng the Federal Association of Management Board, founded in 1954 (Husin 2011: 228).

${ }^{20}$ The need of the NEP was understandable since, in 1970, almost fifty per cent of all households lived below the poverty line, estimated at thirty-three USD per capita/month. The goals of NEP were to eradicate poverty, irrespective of race or ethnicity, and "to restructure society so as to remove the identification of race or ethnicity with economic status and/or function” (Zainal 2006: 1).
} 
141). ${ }^{21}$ Although clearly manifesting the aspiration to eradicate poverty for all Malaysian citizens, NEP has proven to cater only to the bumiputera. 22 "This has caused the evolution of a de facto two-tier citizenship in the country and has provided the Malay elite with the vehicle for the institutionalization of racism in Malaysia" (Ganesan 2012).

Looking at these two different developments, Suryadinata's identification of ethnic policies as a mirror of demographic structures seems accurate: as we have seen in the Indonesian case, the policies involved not only assimilation, but also expulsion and even murder, whereas in the Malaysian case the policies "only" strived for acculturation.

How have these policies influenced and framed the concept of Chinese heritage in Indonesia and Malaysia? Who belongs to this heritage, and how is it advocated? In the following section I will introduce two different organisations in the field of cultural heritage. The intention is not to compare these organisations, as they are completely different in agency and scope, but rather to show the broad range of expression we can currently find within Chinese heritage discourse. We will see that this discourse works as a corrective to a single-minded state narrative, and even plays a feasible role in the effort to campaign for a multicultural agenda in both Indonesia and Malaysia.

\section{The Organisation Boen Hian Tong in Semarang on Java, Indonesia}

Located on the north-eastern coast of central Java, Semarang is one of Indonesia's ten biggest cities with approximately 1.5 million inhabitants, of whom 225,000 are expected to be of Chinese descent. ${ }^{23}$ For Indonesia in general, the population of Chinese descent was estimated at around three per cent in 2009 , which equals $7,834,000$ people, a number that is currently decreasing ( $\mathrm{Li}$ and $\mathrm{Li}$ 2013: 23).

Boen Hian Tong (BHT), located in Pecinan, Semarang's historical Chinatown, ${ }^{24}$ can boast of 145 years of uninterrupted existence and can be regarded as emblematic

${ }^{21}$ During my visit to the National Archive in the 65-story building Komtar in Penang in December 2014, no person of Chinese descent seemed to be employed in any of the administrative sectors visited. When hearing about my connections with Germany, the Malay clerk broke out in sheer joy, exclaiming how Hitler's strategies would be badly needed in those days in order to tidy up the global Chinese mess.

${ }^{22}$ Although bumiputera implies being Malay Muslim, Muslim Indians might as well have a slight chance to be entitled to enjoy some of the bumiputera privileges.

${ }^{23}$ The estimation for Semarang is based on the statement by Harjanto Kusuma Halim, the head of BHT, which seems as a plausible one taking Willmott's statistics from 1955 into consideration (Willmott 1960: 7-9). However, due to all the inaccuracies he found both in the city population reports and the civil registration records, Willmott could not be certain himself (ibid.: 359).

${ }^{24}$ Pecinan was designated for the Chinese in the aftermath of the 1740 Batavian massacre (Jakarta). 
of Chinese heritage and interaction in the city, which might also be indicative of the situation of Chinese Indonesians in other parts of Java.

Apart from Semarang, there are a number of cities in Indonesia where the Chinese heritage is also manifested in Chinatowns: Bandung, Jakarta, Malang, Solo, and Surabaya in Java; Medan and Padang in Sumatra; Makassar and Manado in Sulawesi; and Pontianak in Kalimantan (Alkatiri, Irmayanti, and Waworuntu 2015). Apart from two rather slim yearbooks (1976 and 2007) and a short article in a booklet about Pecinan's Imlek festivities (2014), there are no written sources about BHT. ${ }^{25}$ In general, there are hardly any available data on Chinese heritage in Indonesia, which makes research very challenging, naturally resulting in a rather modest research outcome.

According to Willmott (1960: 130), BHT was the earliest "social club" in Semarang, founded in 1876 as a Chinese music society and initially open only to wealthy men of high social ranking. Over time, this "social club" changed its raison d'être away from elitist mutual-aid activities in order to become social in the broader sense of the word. This means that the organisation has provided a venue for both weddings and funerals, as well as financial help to destitute citizens, irrespective of their ethnic background. ${ }^{26}$ Since the beginning of the twenty-first century the venue is also serving as a location for inter-religious ceremonies.

When did these changes of organisational profile occur? How did the Japanese occupation influence the activities of BHT? What happened during Suharto's New Order regime? The challenging task of researching BHT's history follows the hypothesis that, in observing these changes, we can find a testimony of the assimilation process that was forcefully implemented through the assimilation policies under Suharto's rule (1966-1998). If analysed concurrently with the Chinese Indonesian history as shortly outlined in the first part of this article, a chronicle of BHT can provide indications of the momentousness of various anti-Chinese policies, as it depicts how the organisation had to react to their implementations, which could be indicative

\footnotetext{
${ }^{25}$ After fourteen months of research, I finally received the yearbook of 1976, "1876-1976 Buku Peringatan H.U.T. ke 100, Rasa Dharma d/h Boen Hian Tong, Semarang" [Commemorating one hundred years of Rasa Dharma/Boen Hian Tong, 1876-1976, Semarang] (Anonymous 1976). The yearbook of 2006 - "1976-2006 pecinan semarang dari Boen Hian Tong sampai Kopi Semawis" [Chinatown of Semarang, from Boen Hian Tong until the festival of Kopi Semawis, 1976-2006]is rather a booklet, and it was self-published just as the yearbook of 1976 . The article of 2014 is to be found in the booklet "Pasar Imlek SEMAWIS CIA GWEE 2565, 27-29 Januari 2014 Wot Gandul Timur - Gang Pinggir, Semarang [New Year Festival - Kopi Semawis traditional market in the lunar year of 2565, January 27-29, 2014, East Wot Gandul Area - Gang Pinggir, Semarang].

${ }^{26}$ Chee-Beng Tan $(2012 ; 2018)$ shows how the practice of shàntáng 善堂 (charitable halls/benevolent society), which emerged in China already during the Ming dynasty (1368-1644), has been carried on by Teochew migrants in Malaya. Here we can see that in various ways BHT - along with other Chinese organisations in Indonesia-follows the same tradition of providing charity to individuals regardless of their ethnic affiliation.
} 
for the destiny of many Chinese Indonesians in Semarang and possibly also for Chinese Indonesians in other parts of Java.

According to most interviewees, the first members of the "social club" were in their majority Dutch educated Peranakans of high social standing who gathered to listen to indigenous Indonesian musicians playing Lam Kwan (Chinese string and wind instruments) for them. ${ }^{27}$ It is also very probable that gamelan, although not related to traditional Chinese music, was also part of the musical repertoire. ${ }^{28}$ There was a famous Peranakan, Tan Tiang Tjhing, who pioneered a fashion for gamelan in Semarang already in 1814 (Coppel 2013: 350). BHT was established in a house in the Gambiran street in Pecinan on February 9, 1876 (also referred to as year 2427 according to the Chinese calendar) by "Luitenant der Chinezen" Tan Ing Tjong. ${ }^{29}$ BHT was also referred to as Wen Xian Tang (wénxiàntáng 文献堂), “a room to preserve books of historical value" (or library), and was acknowledged by the Dutch government. The number of members was limited to 500 and the election eligibility criteria were restricted to healthy members of "high social standing" between the age of eighteen and fifty years old. A registration to the board along with a health check-up or a medical certification were also needed, as well as a signature promising to comply with the organisation's rules and regulations. From being merely a social gathering, BHT added a new scope and became a funeral association as well. ${ }^{30}$ Money was collected for grieving the deceased members of the club as well as their deceased relatives, a practice that led to the establishment of a funeral fund. The Sangseng (Chinese:

\footnotetext{
27 "Peranakan" or "Baba" are different terms referring both to the culture and the individuals related to it that emerge from the intermarriage between Chinese and local Southeast Asians of Indian, Indonesian, Malaysian, or Thai origin. Originally these terms referred only to the offspring of a Chinese male and a local female, since it was only the patrilineal structure that mattered within Chinese culture. If the mother would be Chinese and the father Malay, the child would be regarded as Malay. Anak in Per-anak-an is the Malay/Indonesian word for child, with the dictionary definition being "offspring of indigenous and foreign" (Coppel 2013).

${ }^{28}$ Gamelan: traditional music of Bali and Java that is played in an ensemble, including xylophones, bamboo flutes, and percussion instruments. In nineteenth-century Java, it was common to pay back debts in the form of a gamelan set. Since the members of BHT belonged to the wealthy strata of society, it is very probable that the gamelan set, that for many decades was part of the organisation's interior, had this background (Interview with Widjajanto Dharmowijono on January 22, 2015).

${ }^{29}$ During the Dutch colonial era, a form of administration and control of the different minorities included the assignment of power into the hands of authoritative and powerful individuals within the different ethnic communities. Appointed by the Dutch, they had military titles: Majoor, Kapitan, and Luitenant, all taken over from the Portuguese.

${ }^{30}$ According to Fauzan Hidayatullah (Interview on January 24, 2015), an active member of BHT, this happened as the Indonesian musicians playing Lam Kwan died and the Chinese wanted to pay them tribute. Fauzan Hidayatullah himself is Indonesian without any Chinese background, but took on the Chinese sounding name Chen $\mathrm{Fu}$ Shan out of interest in Chinese culture.
} 
shǒuling 守) and Maysong (Chinese: chūbin 出殡) rituals were also performed. ${ }^{31}$ After the funeral, the name of the deceased would be carved into a board referred to as San Hiang. The idea was that co-operation and solidarity among the members, regardless of their individual social standing, would increase if certain rules would be implemented. Religion was originally not a matter of concern, but there was an altar for the god of music and occasional praying ceremonies for deceased members would be arranged.

The beginning of the twentieth century can be referred to as BHT's golden era, prosperous for the Chinese Indonesians in Semarang in general as can be seen in: the establishment of the Chambers of Commerce; the spread of Sun Yat-sen's revolutionary thoughts; arrival of Chinese consuls; prolific Chinese press. According to the yearbook, the leadership of the organisation was in the hands of Oei Djie Sien (18351900) between 1916 and 1924, also referred to as the "right hand" of Oei Tiong Ham (1866-1924; elected as Majoor in 1896). As one may observe, for some reason, the contributor to BHT's yearbook of 1976 used the deceased Oei Djie Sien to "cover up" for the leadership during this period. ${ }^{32}$ Oei Tiong Ham, also called Rasa Gula (Sugar King), was the owner of Tiong Ham Sugar Concern and the founder of the first multinational conglomerate in Southeast Asia, making him the richest person of the entire region at the beginning of the twentieth century. Due to his enormous wealth and high social standing, Oei Tiong Ham was one of the very few Chinese Indonesians who were permitted by the Dutch administration to wear western clothes, cut the Chinese queue, and live outside of Chinatown. ${ }^{33}$ In his role as a progressive stakeholder, he also managed to improve the situation of the people in Chinatown through his pressure on the Dutch administration to eliminate regulations that hindered the Chinese community from thriving (Tio 2013: 30-31). Although spending the last years of his life in Singapore, Oei Tiong Ham had a widespread influence on the Chinese community in his city of birth. ${ }^{34}$ In the period between 1916 and 1924, the venue of BHT was not used for praying ceremonies anymore, but instead served as a Convention Hall for

\footnotetext{
${ }^{31}$ Maysong refers to the ritual the night before the burial, where people gather at the house of the deceased, and Sangseng refers to the ritual in the morning of the burial, when the coffin was picked up at the house of the deceased and taken to the cemetery. There was a strict dress code for this event: white outfit, black hat, white or black shoes, while the members were not allowed to laugh on the way to the cemetery.

${ }^{32}$ It is not improbable that Oei Tiong Ham himself was the leader of BHT during these years.

${ }^{33}$ The Dutch policy of segregation was not restricted to Chinese and Indonesian exclusion from certain residential areas, hotels, resorts, and the Dutch school system, but also included severe penalties for individuals caught using the Dutch language (Willmott 1960: 22).

${ }^{34}$ In 1910, Oei Tiong Ham donated 10,000 USD to the Tao Nan School which was later turned into the Singaporean Peranakan Museum, and in 1919, 15,000 guilders for the construction of a secondary school in Semarang (Tahir 2008; Willmott 1960). He is also commemorated with a street name in the city of Singapore, the Oei Tiong Ham Park.
} 
wedding and art performances. For several decades, there were only a few premises for wedding ceremonies in Semarang, which also increased BHT's popularity.

In February 1935, the board of BHT decided to allow the first woman, Mrs. Kam Siok Bian Nio, to enter the organisation. She became member number 657 on February 9,1938 . This could possibly be indicative of the organisation's rather progressive identity compared to the standards of overseas Chinese, especially those in Malaya. ${ }^{35}$ It could also be evidence of the Peranakan domination of BHT, as by Totok standards,${ }^{36}$ being more traditional in habits and education, it might not have been regarded as appropriate to let women enter this male dominated area. During this period, the organisation started to carry out different kinds of social work for poor and destitute, regardless of their ethnical affiliation.

During the interregnum between Dutch withdrawal and Japanese rule in 1942, a large number of Chinese Indonesians sought refuge in Semarang, as local plunderers (perampok) seized the moment of political instability to attack Chinese property in the countryside (Heidhues 2003: 3). The Japanese forcibly merged all Chinese organisations into one central association, initially called Tiongkok Djin Hui (Huáqiáo zóng hui 華僑總會, Overseas Chinese Association; Japanese: Kakyō shōkai). Each city or municipality had its own association that was responsible for maintaining their community under control and collecting funds for the Japanese War, while also carrying out welfare activities for the dismissed organisations (Willmott 1960: 137). Although the leadership of the different associations remained Chinese, it had to be approved by the Japanese. BHT was no exception and during the organisations' suspension it was integrated into a branch of Tiongkok Djin Hui. The Japanese confiscated all BHT's furniture and used them at their own headquarters and also apprehended most of the board members. ${ }^{37}$ The organisation was closed until August 17, 1945, two days

\footnotetext{
35 The comparison between Malaysia and Indonesia is too complex to be discussed here, as most overseas Chinese organisations in Malaysia are clan-structured. Yet the fact that Khoo Kongsi in Penang (see further below) did not extend their funding to include women until the 1990s might be significant (Interview with Cheah Cheng Seang in Penang on December 12, 2014).

${ }^{36}$ Totok (in the twentieth century also referred to as Singkeh, deriving from Chinese for "new guest") means "pure, genuine, full-blood," and is thus an antonym of Peranakan. Totok usually speak Chinese, or one of the dialects of origin, and are culturally oriented towards China (Tan 1991: 120). Peranakan and Totok often went to different schools, had different customs, pursued different careers, lived in different neighbourhoods, and spoke different languages, thus being regarded as two different cultures within the Chinese community (Willmott 1960: 103-116).

${ }^{37}$ According to Jongkie Tio, an active member of BHT and self-learned historian, the Japanese occupation was facilitated with the help of a fifth column, referring to "a group of people who undermine a larger group from within." In this case the fifth column were the Japanese who had lived in Semarang as petty traders, but as soon as the Japanese occupation began, they changed their identity to officially become part of the military. As the Japanese had access to the register of financial contributions to mainland China during the Japanese War, an important issue on the agenda was to punish all individuals on the list. Death penalty was the common retribution (Interview with Jongkie Tio on January 19, 2015).
} 
after the Japanese surrender. The activities of BHT were resumed under the leadership of Liem Siauw Tjong (1903-1987), who remained in a key position of the organisation until the middle of 1966 . The election process was a biennial matter, where the outgoing officers would nominate a rather high number of members, among which all members would vote for twelve of them by a secret ballot. The twelve candidates with most votes would then divide the offices among themselves, which means that "the formal structure of Chinese organizations is thus seen to be quite democratic" (Willmott 1960: 145-146).

There is little information about the years between the Japanese interference and Suharto's rise to power, other than the organisation's growing due to old members renewing their membership and new ones being accepted. It is possible that this era was marked by a shift away from the "elitist" approach that had prevailed prior to the Japanese occupation and described by Pandji B. Suprana (1914-1983; chairman 1974-1977) as the need for reflecting "quality" and not "quantity" in the membership (Yearbook 1976).

The 1950s were marked by regained economic strength, as the city's total volume of production "was turned out by Chinese enterprises" (Willmott 1960: 44), which accounted for approximately seventy-five to eighty per cent of Semarang's entire business activities. The Presidential Regulation No.10 (Peraturan Pemerintah), also known as PP 10/1959, was adopted in 1959, prohibiting foreigners from business activities in rural areas. Although on paper this was an initiative against all kinds of foreign involvement, with the aim to strengthen the indigenous Indonesians (pribumi), ninety per cent of the businesses affected by the regulation were in the hands of Chinese Indonesians, which resulted in a rural exodus and a strong influx of Chinese Indonesian migrants to Semarang (Tio 2013: 93). Oei Tiong Ham's successful welfare fund Kian Gwan, founded in 1863, was also discontinued as it became nationalised in 1961 (ibid.: 32). After the display of Pancasila and the photos of President Suharto next to the second vice President Sri Sultan Hamengku Buwono IX (b. 1946; in office 1973-1978), the organisation's yearbook of 1976 starts with an introduction by Semarang's Mayor and the Head of the Social Department. None of the persons mentioned had any connection to BHT. This is followed by a brief introduction to the organisation, images of committee members, and various articles by authors who do not explain who they are or how they are related to BHT.

The topic of the 1965 tragedy is completely ignored, which is indicative of the lack of sources to express anything that could be regarded as controversial during those years. Although many of BHT's members-like other people of Chinese descent all over Indonesia - had been persecuted, had their homes and belongings looted, destroyed, or even burnt down to the ground, there were no initiatives to confront this 
abusive turmoil among the Chinese Indonesians. On the contrary, they kept distance and rather avoided each other. ${ }^{38}$

On June 16, 1966, BHT had to change its name as all Chinese names had to be converted into Indonesian. ${ }^{39}$ BHT was changed into Budi Dharma and then into Rasa Dharma on December 17, 1966, as there was already another organisation with the name Budi Dharma. In the following three years, BHT had to sell its most valuable assets, namely most of its real estate in order to restore the building (Yearbook 1976). What is not mentioned in the yearbook is that the restoration was enforced in order to change the façade, as it was carrying "Chinese features."

One of Suharto's policies from 1967 promulgates that "Chinese practices of observance which possess aspects of cultural affinity which have their source in the country of their ancestors are all those forms of activity such as the realisation (perwujudan) of the internalizing (penghayatan) of beliefs, religiosity (kerokhanian) and spirituality (kejiwaan) which have characteristics and features of Chineseness (keChinaan)" were banned from the public space (Coppel 2002: 38). This meant that religion became forbidden in the public space and that BHT arranged an altar for praying ceremonies within their premises. In 1967, the rules of BHT were also changed in order to encourage non-Chinese membership. According to the yearbook from 2007, a library was opened in 2005 , with a limited collection of approximately eighty volumes of high value due to their uniqueness. However, at the time of research (20142015), no library was available as the books had all been "stolen," which rather means that they were preserved by other members as they were afraid that these precious volumes could easily disappear, as had been the case with so many other items of value through the course of BHT's history. The books that are currently regarded as important for the Chinese Indonesians in Semarang are kept in private and access was denied throughout the entire period of my research.

During the "state orchestrated violence" in May 1998, when "the regime both cultivated and responded actively to the expression of popular anti-Chinese sentiment on Java by stoking those prejudices and giving them official cover" (Panggabean and Smith 2011: 234), large scale violence spread along the road between Surabaya and Semarang - but Semarang was essentially saved from any major disturbance. After these calamities it became clear to a fraction of the Chinese Indonesians that there was a need of self-protection for people of Chinese descent and that this had to be organised politically.

\footnotetext{
${ }^{38}$ Various interviewees depict the situation as stated above. One interviewee had his shop looted and burnt while another had to help deconstructing his own century old heritage villa due to its Chinese architecture, as this kind of architecture had no place in the new Indonesian nation state (Interview with Boen Hian Tong members on January 23, 2015).

${ }^{39}$ This name-change was a political imperative. It was carried out on an individual basis, often trying to represent the old Chinese name within the new Indonesian one.
} 
As the ban of ethnic-based parties was lifted in 1999, political activities among people of Chinese descent were reinitiated. Abdurrahman Wahid (Gus Dur) was proclaimed Bapak Tionghoa on March 10, 2004, while visiting Tjay Kak Sie, the main klenteng of Pecinan in Semarang. This was an event of great importance as the BHT board members put it: "Gus Dur has a special place in the heart of the Chinese, especially in Semarang" (Interview with BHT board committee on January 23, 2015). As a sign of devotion, Gus Dur also received a commemorative tablet placed next to the altar, being the only Javanese throughout BHT's history to have a plaque at their premises. Gus Dur's official pronouncement that he too was "to a certain extent Chinese" had direct impact on the functions of BHT.

Calligraphy courses, gamelan for children, different seminars on Chinese culture, screenings, book presentations, and puppet theatre (Wayang Potehi) show how the activities have increased since Gus Dur's presidency, which was also marked by the revoked status of Confucianism and the appointment of Chinese individuals in high political positions (Suryadinata 2001: 521). More social gatherings such as line-dance, table tennis, tàiji 太極, and other activities suitable for an organisation of which most members are older than sixty years of age started to take place in the venues on a daily basis. A fitness studio also became part of the building in 2004. There are two more recent events that have been mentioned on several occasions and seem to be characteristic of BHT's self-perception. The first event is a talk-show on Chinese culture, where it was argued that the Chinese Indonesians' contribution to the Indonesian society could be more variegated and community-oriented. The second event was a lecture about Gus Dur on August 23, 2014, explaining the fundamental elements of the traditional Chinese culture related to the patrilineal structure and family lineage and connected to the ancestral tablet of Gus Dur. Both events are characterised by a content that opens up a discussion of the Chinese Indonesians' role in contemporary Indonesian society.

Since March 19, 2011, BHT tries to hold a meeting on the fifteenth of every month according to the Chinese calendar. Other activities are also taking place during the Independence Day as well as during the Muslim New Year-all attempting to reach out to the surrounding ethnic communities. As commented by the chairman Harjanto Kusuma Halim (b. 1965; in office since March 7, 2010) in the introduction of the 2012 yearbook: "We feel proud to be able to offer a platform for religious life in the spirit of tolerance and mutual respect." All activities are open to the general public. Since 2010, Qingming Jié 清明节, the “Tomb Sweeping Day”-referred to as King Hoo Ping or Cheng Beng by Chinese Indonesians - is also celebrated at the premises of BHT. 


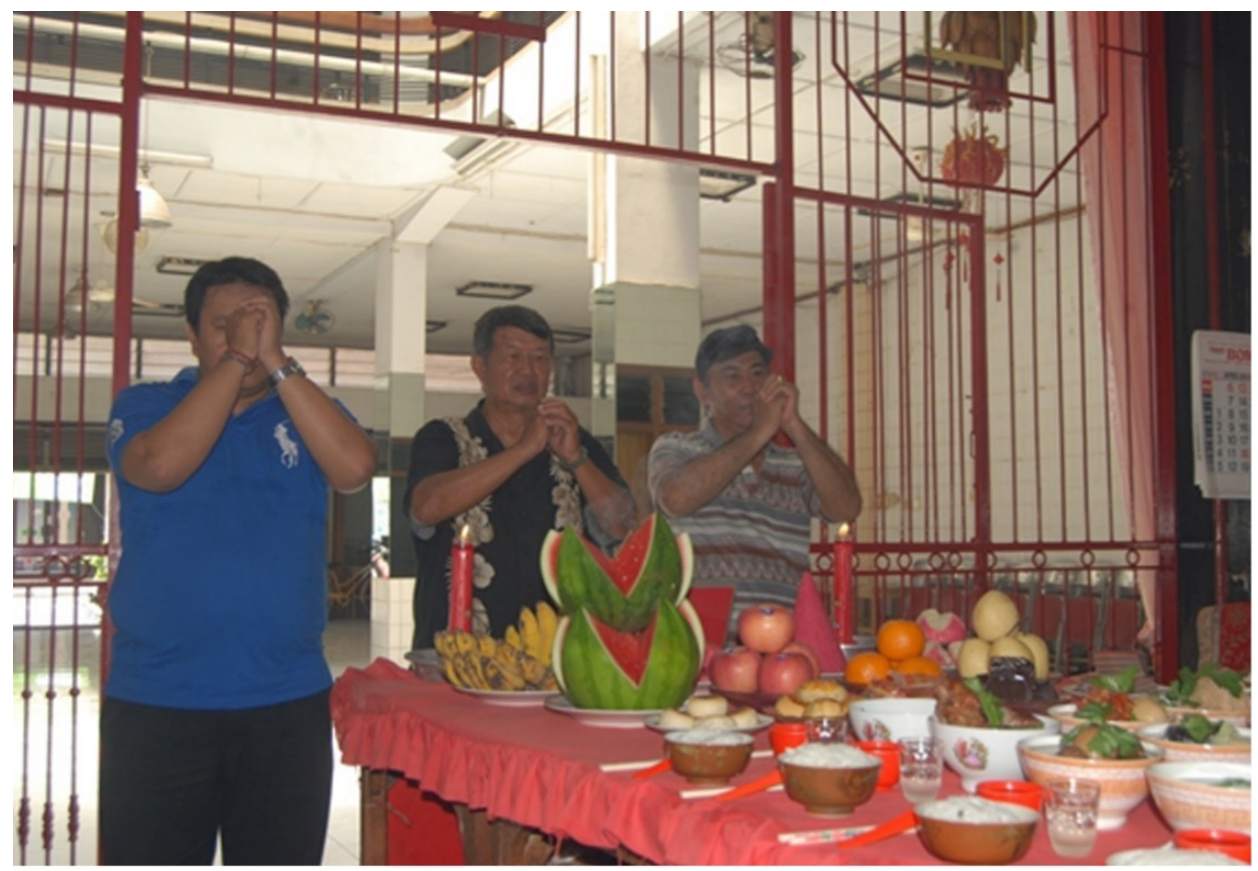

Cheng Beng prayers in front of the altar at BHT, April 4, 2014. (Photo: Rakhmat Yasir Widayat)

The ceremony to remember past ancestors is always conducted during the seventh month according to the lunar calendar and refers to a joint praying ceremony in which six religions are represented: Buddhism, Confucianism, Daoism, Hinduism, Islam, and Catholicism.

The current chairman of BHT is trying to create a new social framework in order to prove that the Chinese Indonesians, who regard themselves as being part of the Chinese community in the city, are open-minded and genuinely interested in their role as representatives of a multicultural Indonesia. One challenging task is to attract the younger generation, which has proven to be rather difficult, as it is an intrinsic value within Chinese culture not to overstep the boundaries of the generations. It would be regarded as disrespectful of younger people to take a leading role within an organisation that predominantly cater to older individuals.

In various respects the trajectory of BHT can be seen as paradigmatic for the destiny of Chinese culture in Semarang during the twentieth century. Four prosperous decades, both in economic and social terms (modernisation in education, literature, and religion), also gained momentum in BHT in 1938, as the first female entered the organisation that had previously been an exclusively male privilege. This social and 
economic upsurge came to a complete halt during the Japanese occupation, when anyone of Chinese descent could be prosecuted without trial. ${ }^{40}$ For BHT, the Japanese occupation resulted in three years of suspension, confiscation of valuable assets, and apprehension of the majority of BHT's board members. The second phase of Chinese Indonesian oppression in the twentieth century started in the 1950s and is not directly reflected in the functions of BHT, as the target was related to economic activities in rural areas and economic nationalisation policies. The third phase of Chinese Indonesian oppression, starting with the "war against Communism" in 1965, and followed by the assimilation policies dictated in 1967 , which lasted until 2000 , is clearly mirrored within BHT. This is visible in a variety of forced changes (name, guidelines, ceremonies, membership, and leadership) that resulted in what the political strategy, as declared in "the Chinese Problem," was aiming for: a slow and gradual dissolution of Chinese heritage. Since the ban of Chinese religion, beliefs, and customs in the public space (Appendix D to Presidential Instruction 14/1967) was lifted in 2000, BHT has managed to regain some life spirit.

The most vivid example is the yearly participation in celebrations during Imlek. In the course of the three days prior to Imlek, Pecinan holds a variety of lectures, performances, exhibitions, and street food festivals, with the venue of BHT playing an important role. The festivities around Imlek are not restricted to Chinese-related topics but welcome any kind of contribution that celebrates Indonesian multiculturalism. However, the traces of thirty-seven years of Indonesian Chinese stigmatisation are clearly visible when analysing the content of BHT:

1) 139 years of history has remained largely unrecorded as artefacts and documents have disappeared (either destroyed or stolen). ${ }^{41}$

2) The few remaining artefacts in the building describing or depicting BHT's past are unintelligible to almost all members, as there are very few individuals who speak Chinese.

3) After the building was forced to remove its Chinese façade, the interior has been adjusted with white tiles that do not reflect Chinese aesthetics.

4) The majority of the current 550 members are older than sixty years of age.

5) More than half of the members are native Javanese without any specific Chinese connections or interests. Further, the consequences of Suharto's anti-Chinese policies are clearly visible in the deliberate neglect of Chinese architecture in Pecinan, which

\footnotetext{
${ }^{40}$ Similar to Malaya, the Japanese were mostly interested in individuals that had been supporting China during the Japanese War. If proven guilty, prosecution was definite (Interview with Jongkie Tio on January 19, 2015).

${ }^{41}$ Most interviewees (all who wanted to remain anonymous) admit to having destroyed a majority of their personal belongings related to China, such as birth certificates, photographs, documents, and books during Suharto's rule for security reasons.
} 
does not accord with the Indonesian Charter of Heritage Conservation (Wijayanti et al. 2014: 56).

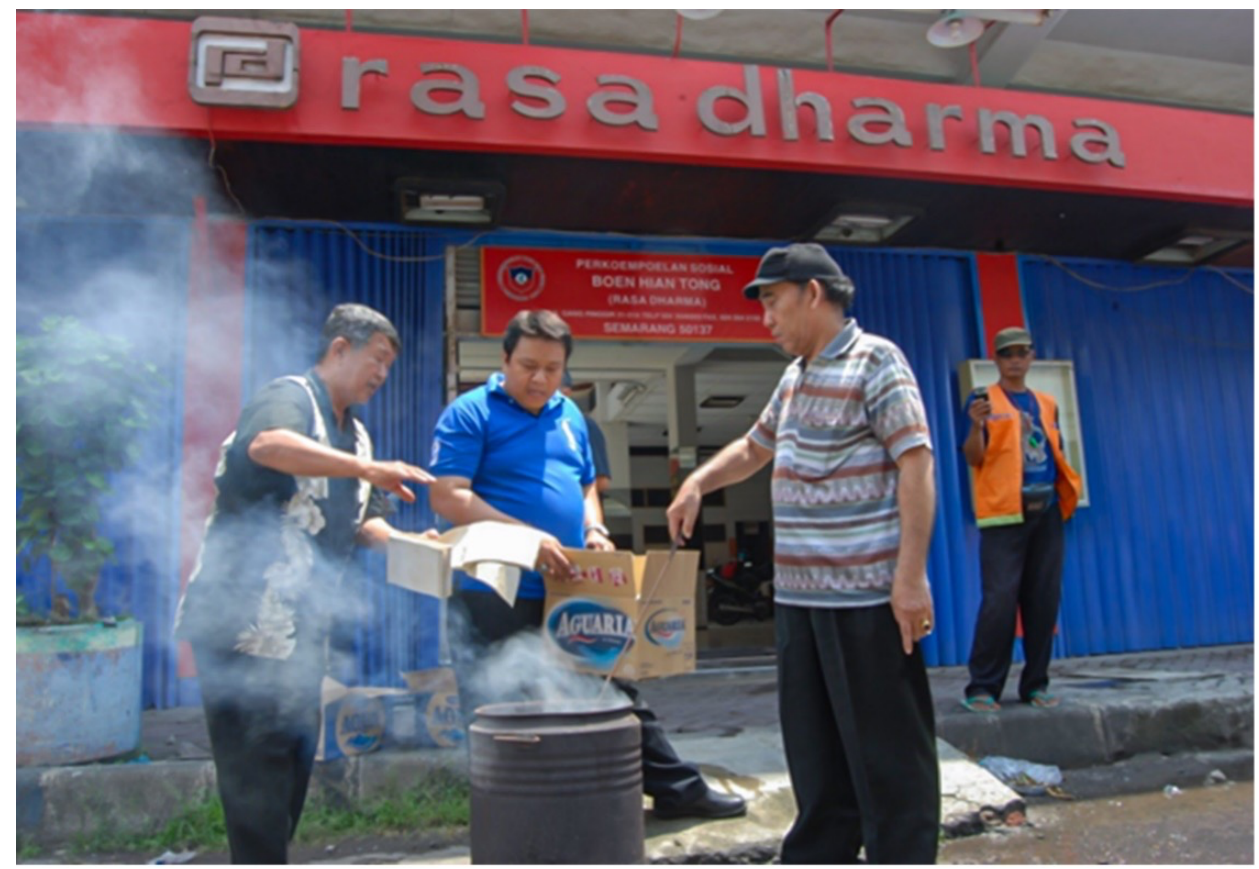

Cheng Beng ritual of burning paper for the deceased in front of the BHT building on April 4, 2015.

(Photo: Rakhmat Yasir Widayat)

\section{A Chinese Perspective of the City of Penang, Malaysia}

Due to its strategic location in the Strait of Malacca along with liberal policies, Penang quickly became a multilingual and mercantile trading centre for "Malays, Indians, Arabs, Chinese, Europeans, Armenians, Burmese, and Thais as well as other peoples from the Malay Archipelago" (Walker 2012: 308). All these groups can be regarded as having participated in the creation of a unique cosmopolitan reality, whereby the Peranakan Jawi (Muslim Peranakan), the Straits Chinese (predominantly Englishspeaking and westernised Chinese), and the Indian Muslims (predominantly the Tamils, often referred to as Keling or Chulia) possibly played decisive roles.

As early as 1833 four major religions (Buddhism, Christianity, Hinduism, and Islam) had institutions of worship in the city, which indicates that "the policy of religious freedom which characterized British rule in Malaya was first articulated in Penang" (Khoo 2010: 274). Shortly after Penang's establishment as an English trading centre, a Chinese from the Kedah province, most probably descended from the Fújiàn 
province, named Koh Lay Huan, became Kapitan (De Bernardi 2009: 17). The responsibility of the Kapitan included the administrative system that recorded births, marriages, and new arrivals. Since religious freedom was propagated, along with the right of the different ethnic groups to follow their own customs, the Kapitan also had to conciliate different kinds of social, legal, and religious conflicts.

The Chinese traders were generally regarded as attractive companions in the eyes of the British settlers due to their valuable products, and they were further the "most valuable" citizens of the settlement due to their "all-round capacities" and their key role in commercial life. As wealthy Chinese held monopolies in important commodities, such as opium and liquor, they came to be regarded as a middleman minority at an early stage of the settlement's history. ${ }^{42}$

At this point it is important to pay attention to the fact that the Chinese immigrants to the island came from different parts of China and had different educational and even linguistic backgrounds that did not necessary create a unifying identity. "The immigrants divided themselves into subethnic communities, each with its own associations and distinctive occupational specialties [...]. Conflict rather than cooperation often characterized the relationship" (De Bernardi 2009: 21).

The immigrants were related to different dialect groups or "speech groups" that were in turn related to different Hui/Huiguăn 会馆 or Kongsi/Gōngsī 公丝 institutions that played a crucial role in the organisation of Penang's social life: "Property rent, investment dividends and bequests were transferred and retained by these communal institutions, leading to an accumulation of wealth for collective and intergenerational disposal" (Cheng, Li, and Ma 2014: 626).

According to Ji (1997: 103), the Gōngsī "which originated in mainland China is one of the key organisations in peninsular Malaysia." Gōngsī and Huìguăn have often been used interchangeably, although Ji opines that Gōngsī changed into Huìguăn in modern times and could refer to: 1) a voluntary association based on dialect groups, created for mutual assistance; 2) a cooperative for tin-mining; 3) a merchant house; 4) an association with a common venture, which could include secret societies; or 5) a company building (Ji 1997). Commonly, Gōngsī can be regarded as a "functional assembly of members" (Küchler 1968: 91) of the same occupation, guild, or clan, with the latter including all individuals who share the same surname that can be traced to a common ancestor.

Penang has been the most vibrant area with a living Chinese heritage in Southeast Asia for an extended period of time. In contrast to Semarang, there has never been

\footnotetext{
42 According to Edna Bonacich (1973: 586) "[m]iddleman minorities typically evince the following traits: a resistance to out-marriage, residential self-aggregation, the establishment of language and cultural schools for their children, the maintenance of distinctive cultural traits (including, often, a distinctive religion), and a tendency to avoid involvement in local politics except in affairs that directly affect their group. They form highly organized communities which resist assimilation."
} 
any Chinatown in George Town, which is logical since the Chinese were for a long time the most populous "ethnic group." Sometimes an "enclave" could be organised around a Gōngsī, providing housing for the clan members as in the case of Khoo Kongsi, one of the Goh Tai Seh (five major surnames) of the Hokkien in Penang. ${ }^{43}$

The Khoo Kongsi, regarded as the most impressive Gōngsī in Southeast Asia, only represents the interests of the male progeny with the surname Khoo from a specific geographical location in the Chinese province of Fújiàn. ${ }^{44}$ Khoo Kongsi provided free education and welfare for their fellow clansmen that had accepted different rules and regulations, which were often concerned with respectable behaviour and veneration of the ancestors, traits that can be regarded as typical for the patriarchal Chinese society.

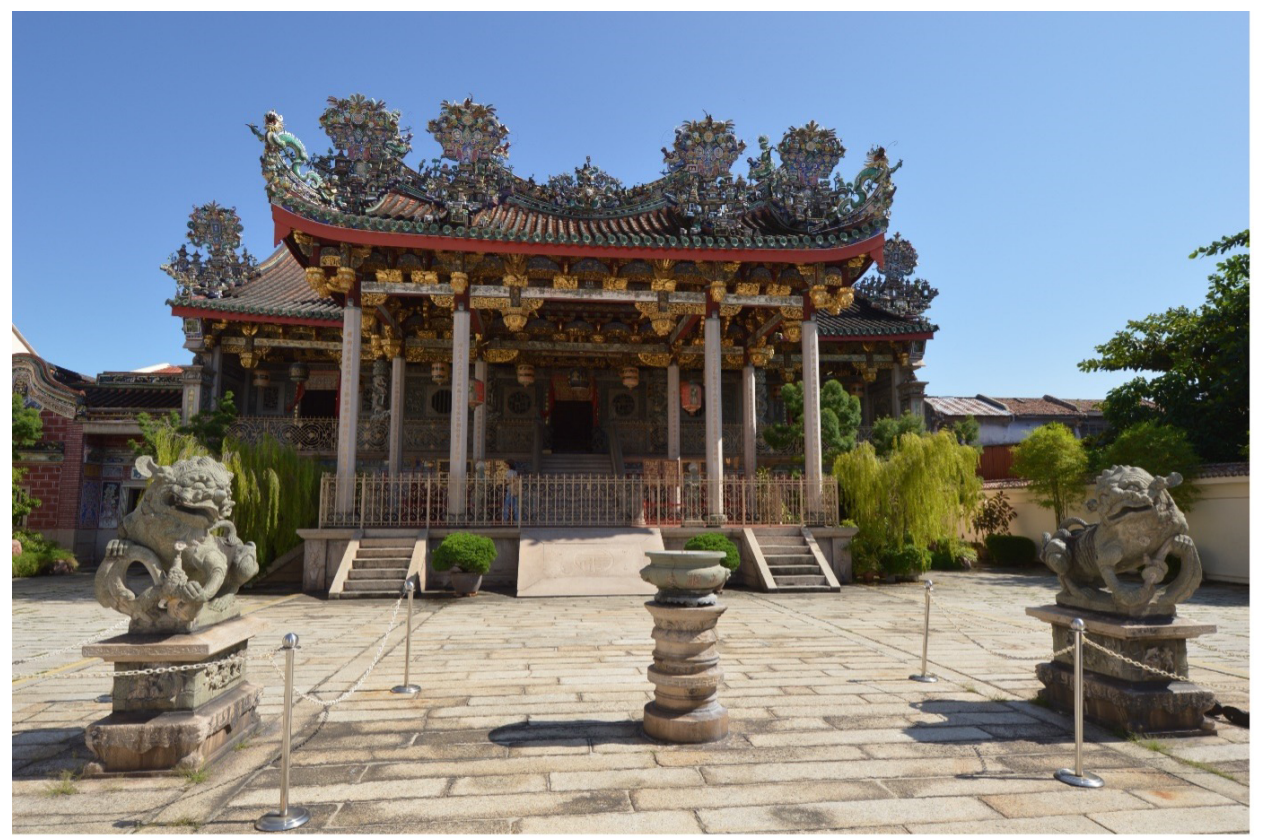

Khoo Kongsi in Penang, January 2015. (Photo: Gabriella Voss)

"The Straits Chinese came to be identified by social-economic class, political orientation, gentrified lifestyle and an eclectic taste for the finest things from all cultures" (Khoo 2007: 16). It is also the material culture of the Straits Chinese that have given

\footnotetext{
${ }^{43}$ The other clans refer to Cheah, Yeoh, Lim, and Tan.

${ }^{44}$ This refers to the Sin Kang village of the Sam Toh county, in the Hai Teng district, in the Chiang Chew prefecture, eight kilometres from the Amoy island (Trustees of Leong San Tong Khoo Kongsi 2003: 2).
} 
the city of George Town its most characteristic traits that are best visible in temple and shophouse architecture.

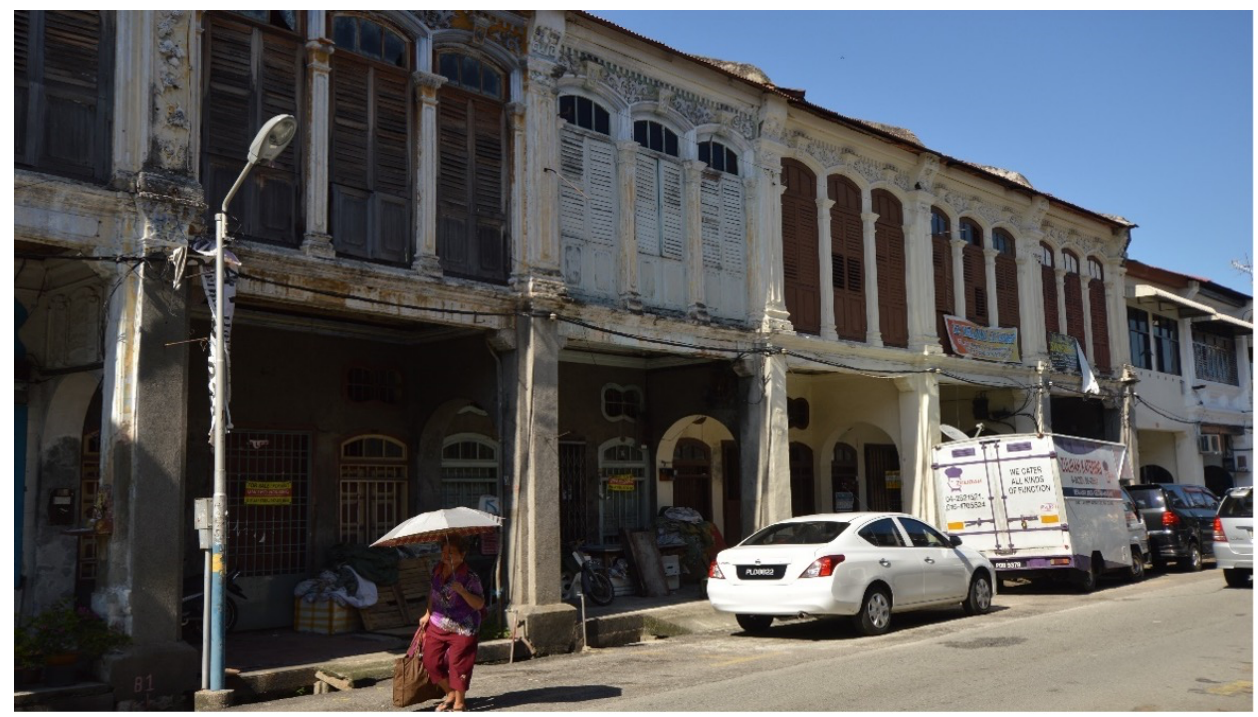

A row of typical Chinese shophouses from the latter part of the nineteenth century. George Town,

December 11, 2014. (Photo: Gabriella Voss)

\section{The NGO Penang Heritage Trust, Malaysia}

Penang Heritage Trust (PHT) is possibly the most influential non-governmental organisation (NGO) in Penang in terms of operating range having the mission "to promote the conservation of Penang's heritage, to facilitate cultural educational programs, to organize public awareness programs and to cooperate with other like-minded organizations in Malaysia and abroad." 45 Established in 1986 as a charitable NGO, PHT has played a crucial role campaigning for George Town's listing as a world heritage site, which was finally accomplished on July 7, 2008. As stated in the mission, PHT is adamant to underscore that the focus is set on the material and immaterial heritage of the whole island regardless of ethnic provenance, actively striving towards a multicultural agenda that would at best be reflected in the organisation's membership. However, when scrutinising the name lists of those present at the Annual General Meetings of 1993, 2007-2008, and 2010-2013, which represents all years with rec-

\footnotetext{
${ }^{45}$ PHT has no other publicly available archive apart from the extensive material through the organisation's homepage (https://pht.org.my/) (accessed: December 15, 2020).
} 
orded annual reports, these names (which in the case of Malaysia can be seen as affirmative of ethnic provenance since mixed marriages are uncommon) show that the Chinese members percentage is well over ninety-five per cent. ${ }^{46}$

Why is that the case when the agenda of PHT is clearly dedicated to the heritage of all Malaysians? It is certainly not the intention of PHT to be a "Chinese NGO"; in fact, the chairwoman Khoo Salma (b. 1963), an acclaimed local historian who has been writing about Penang's history from various perspectives for more than two decades, has tried to reach out to individuals of other "communities" but these efforts have not proven to bring any long-lasting results.

In the following a selection of PHT's prolific work will be introduced. In 1993, heritage became part of the agenda with four different projects. The short-term project targeted the restoration of the Syed Alatas Mansion with the additional aspiration of turning it into a heritage resource centre where additional training of conservation skills to preserve particular Malaysian traditional craft would be practiced. ${ }^{47}$ The long-term projects involved the cleansing of the Protestant Cemetery and the recovery of the Anglo-Indian mansion Suffolk House. It is clearly visible that these projects all set out to protect what the NGO regarded as crucial landmarks of the city without following any specific ethnic agenda but, instead, paying tribute to the extraordinary multicultural heritage of Penang.

"The melting pot" in 1992 was an initiative of the Deputy Prime Minister at that time, Anwar Ibrahim (b. 1947), following an idea of the Harvard Professor Tu Weiming (Dù Wéimíng 杜维明; b. 1940) and in reaction to Samuel Huntington's (1927-2008) theory about the "Clash of Civilizations." Tu's ideas also inspired the Malaysian Civilisational Dialogue between Islam and Confucianism in the following years (Khoo 2010: 287). The "melting pot heritage map" is one example thereof: illustrating a trail stretching over approximately one kilometre in the centre of George Town, housing eleven important places of worship of seven different major religions. The area in which the trail was located took on the nickname "Street of Harmony" and would later turn out to be related to one of PHT's most noted achievements. In the following years the inner city of George Town became of increasing concern, intimately related to the repeal of Rental Control. The Malaysian Control of Rent Act was passed in 1966 following the Control of Ordinance, which was enacted in 1948 to help returnees in the wake of World War II. "In a sense this was a socialist piece of legislation inspired by the British Labour Party" (Hashim 1997: 4) that had the objective to protect tenants against greedy landlords, as neither could the rent be increased, nor could the tenants be evicted. As a result, the tenants started to sublet the premises

\footnotetext{
46 This was also mentioned in an informal interview with a PHT volunteer on December 11, 2014, who stated that "PHT is basically ninety-nine per cent Chinese."

47 The Mansion of Syed Mohamed Alatas (also referred to as Al-Attas) "is a well-preserved example of an early Straits Eclectic-Style Muslim bungalow” (Khoo 2007: 35).
} 
to others, making big profits in the process, and as the owners could not make any claims on their premises, investments and reparations were seldom carried out. As a result, a big part of the inner city was greatly neglected.

In 1997, a rent repeal Act came into force, with a twenty-eight-month transitional period that was meant to alleviate the situation of the tenants that needed to find new housing, while rental increase remained restricted by law. As the phase of transition came to an end in 2000, many low-income tenants had failed to find new housing and were also incapable of paying the new rent that normally increased between fifty and 300 per cent. In George Town this had serious consequences for small-scale businesses carried out in the old shophouses that had survived for many decades. As many of the rent-controlled premises were old shophouses of historical value, PHT had asked the state government to provide guidelines for the purpose of preservation. An SOS group was also formed to resist abusive landlords, and PHT was involved in a monitoring project with the same objective. In this respect, PHT can be regarded as a social organisation, as they sided with poor tenants and tried to help them find solution to this conflict that evicted more than "529 premises on 123 streets of George Town" (Atsumi 2003: 34) in 2000. Concurrent with these changes at the historical centre of George Town, a massive mall complex was under construction, causing damage to at least 150 old buildings in the neighbourhood as an inadequate system of piling was being used. PHT was also actively participating in various action groups to bring the inappropriate construction methods to a halt.

In the 1990s, Penang showed an increasing interest in the potential of cultural tourism, which meant a shift to promote inner-city tourism next to the existing beach tourism that had already given Penang its share of visitors for decades. When Richard A. Engelhardt, the UNESCO Regional Advisor for Culture in Asia and the Pacific, visited Penang during the Hindu Thaipusam festival, he observed that Guānyīn 觀音/观 音, the Chinese Goddess of Mercy, was also venerated, which made him exclaim that George Town "is more than historical layering - it is cultural fusion" (Khoo 2010: 286). As a consequence of this new perception, that beach life and profoundly rich heritage could be combined into a lucrative tourist business; the slogan "we have it all" was coined and Engelhardt advised George Town to apply to be listed as an UNESCO World Cultural Heritage.

In 2005, PHT initiated the "Living Heritage Treasurers of Penang Awards" (LHTA). As the first project of this kind in Malaysia, the intention of LHTA was to revitalise different endangered trades and, as Penang's heritage is very heterogeneous, any traditional craftsman could apply to participate in the "competition." 48 The two winners would be rewarded with an annual sum of money for the rest of their lives, an incentive that aimed to both boost the pride of the craftsmen and also guarantee

\footnotetext{
${ }^{48}$ Craftsman is an accurate term as female participation has been very marginal.
} 
that the trade could be actively carried out. In 2007, out of fifteen nominees, six persons of different crafts (calligraphy, gold smithy, menorah dancing/ "shamanism," lantern making, artisan carving, and artisan craftsmanship) were shortlisted. In the name of protection and conservation of immaterial cultural assets, a menorah dancer and teacher, who is also known as a "spiritual shaman" and practitioner of Thai Wayang Kulit (shadow puppet performance), won the first prize, a nomination that also recognises the historical connection between Thailand and Penang. The second prize went to Penang's last traditional lantern maker. ${ }^{49}$

As a consequence of reinforced bumiputera empowerment, many street names in George Town that evoked the memories of the colonial era were changed into "Malay" names, where Muslim religious connotations played an important role. In this context, the "Street of Harmony" described above was not universally accepted, since a big part of the trail took place in a renamed street housing an important Mosque (Masjid Keling) and had to be changed into "World Religions Walk." However, the intention remained the same: to provide both local and foreign visitors with an opportunity to grasp the multidimensional essence of Malay history, portrayed through the different religions, while also highlighting the importance that "different people at different times for different reasons create different narratives of belonging" (Ashworth, Graham, and Tunbridge 2007: 6).

Following the Swiss theologian Hans Küng's (b. 1928) draft on a "Declaration Toward a Global Ethic" in 1993, and the Berlin-based Konrad Adenauer Foundation's exhibition on "Global Ethic" in Malacca in 2005, George Town was seen as the perfect location to "accommodate interfaith dialogue" (Khoo 2010: 288). PHT provided free heritage walks within the "Penang Global Ethic Project," which started in 2006 as an attempt to "superimpose the idea of interfaith harmony on a historic site, as a strategy to open up a space for inter-religious learning and dialogue" (ibid.: 291).

Another heritage education project, partly financed and carried out by PHT, was a programme called Anak-Anak Kota (Children of the City), in which intercultural teamwork was encouraged for young people between ten and nineteen years of age. Stretched over four to six months during the spring of 2006, this ethnomusicologist project recorded and merged voices and sounds of the city as a social incentive to promote tolerance and cultural diversity: "By crossing stylistic and ethnic boundaries and appreciating cultural differences, they help children to develop perspectives that are more inclusive and so challenge the dominant discourse of ethnicism" (Tan 2008: 71). The project was divided into various areas, with theatre research focusing on the processual act of development (based on a mixture of Berthold Brecht and Augusto Boal), and a "Music of Sound" project, in which the cultural heritage of different

\footnotetext{
49 This lantern maker has not been willing to take on apprentices to learn his skills, which corresponds with the situation in Malacca where the last lantern maker also refuses to pass on his skills.
} 
communities was mapped out and interpreted through music that was finally presented in the Kisah Pulau Pinang (The History of Penang) at the Khoo Kongsi.

The clan jetty information center was another PHT initiative to strengthen the selfperception of a specific community of George Town that had long been marginalised.$^{50}$ After the destruction of the two clan jetties Koay and Peng Aun in 2006, and despite the forceful heritage advocacy to save the Koay jetty in the years prior to demolition, PHT set out to work with scholars, photographers, graphic designers, and residents to visualise the heritage of one of the remaining clan jetties in large scale posters. As these posters were located at the gateway of the jetty, residents and visitors could meet in an informal way and interested jetty inhabitants could take on the role of an expert of his or her own residential area. The destruction of the Koay jetty, inhabited predominantly by Chinese Muslims (alleged descendants of the Hui), exemplifies the difficulty of finding "the golden middle path" between the diverging interests of local residents, heritage agendas, developers, and the general aspiration of tourist agents to attract some of Penang's increasing number of foreign visitors with yet another "exotic" location. The campaign to save the Koay jetty was carried out in a variety of ways (petitions, signature campaigns, news articles, press conferences), which culminated in the publication of the trilingual brochure The Endangered Koay Jetty (Graezer Bideau and Kilani 2009: 156). One contributor to the brochure chose to highlight the "ancestral purity" of the clan community as the reason to save the jetty, while also underscoring how the jetty's coherent community was harmoniously united in a specific and unique blend of both Muslim and Confucian cultural elements. Graetzer Bideau and Kilani (2009: 157) argue that, through the construction of a "pure" Koay identity, the true heterogeneous social reality was denied: "Once a composite and marginal place, in short 'ordinary', the Koay jetty was on its way to being transformed into a homogeneous and central space, in short a 'site of memory'." PHT also stated that one of the reasons to save the jetty was related to the well-preserved Chinese Muslim heritage; but there was also another reason, which was linked to the social history of Penang, as the jetty represented a part of the island's working-class history, being the location where some of the harbour labourers settled at the end of the nineteenth century. The questions arising when arguing for the preservation of the Koay jetty take us to the very heart of heritage discourse, where different ideas, even within the same "action group" (as seen in the case of the contributors to the brochure), partly contradict each other. On the one hand, the argument put forth is that Penang is unique because it displays something different than just two centuries of "ethnic cohabita-

\footnotetext{
${ }^{50}$ A jetty refers to a housing structure built on stilts in the sea. Originally created by Chinese coolies searching for employment in Penang at the end of the nineteenth century, the collective coolie housing evolved into individual family units. At the end of the 1960s, there were eight jetties on the outskirts of Penang, each occupied by one clan (Graezer Bideau and Kilani 2009).
} 
tion": it demonstrates a historical mixing and blending, which at times has even created unparalleled elements of syncretism in architecture, language, food, street art, and religion. On the other hand, it is argued that Penang's uniqueness is the result of long-lasting traditions and customs - manifested both in tangible and intangible heritage as customs are also expressed in the material culture - passed on to the subsequent generation in alleged "pure lineage," and it is this "purity" which can be regarded as worthy of protection. How can an acceptable interface between these two perceptions be negotiated? How much "social reality" can a heritage site openly represent while simultaneously being conscious of the necessity of a "mythical dimension" to gain recognition and interest from the outside (visitors to the site and international recognition)? When identities are becoming essentialised (through an imagined lineage), what possibilities do the affected individuals have to oppose this narrative? Where is the borderline between a continuation of "business-as-usual," allowing for dynamics of change for the inhabitants of the site, and a museumification that blocks these initiatives in the name of heritage protection? When walking on the jetty among other visitors in 2014, my query was how to exist in a neighbourhood that slowly, yet steadily, is being turned into an outdoor museum? To find acceptable answers to all these questions has proven to be one of the major challenges for PHT after the UNESCO listing of Penang in 2008.

After an unsuccessful attempt to be listed as UNESCO World Cultural Heritage in 2002, George Town finally achieved its aim in 2008, together with the city of Melaka, that had also failed to be listed in the 1980s and 1990s, albeit on completely different grounds than George Town. In Melaka, the Chinese history is "essentially absent from heritage representation" (Ashworth, Graham, and Tunbridge 2007: 153), which was also visible in the attempt to expropriate a Chinese burial site in the 1980s.

The two cities of George Town and Melaka can thus be seen as complimentary, as "Melaka, dominated by federal and state apparatuses, is devoted to a museum-type conservation that aims to preserve orthodox history and built heritage. In contrast, George Town, with its vibrant voluntary sector, has nurtured a heritage discourse in which the people, the buildings, and the space they have created, are deemed to be targets for conservation" (Cheng, Li, and Ma 2014: 618-619). ${ }^{51}$

\footnotetext{
${ }^{51}$ There are ten criteria on the UNESCO World Heritage List, and at least one has to be met for a site to be included. Three can be regarded as decisively fitting in the case of George Town. These are criteria number (ii): "to exhibit an important interchange of human values, over a span of time or within a cultural area of the world, on developments in architecture or technology, monumental arts, town-planning or landscape design"; number (iii): "to bear a unique or at least exceptional testimony to a cultural tradition or to a civilization which is living or which has disappeared"; as well as number (iv): "to be an outstanding example of a type of building, architectural or technological ensemble or landscape which illustrates (a) significant stage(s) in human history." See http://whc.unesco.org/en/criteria/ (accessed: December 15, 2020).
} 
This new status of George Town was naturally regarded as an achievement for PHT; however, it also meant an extension of the NGO's field of responsibility. As the government had proven to be inefficient in providing the necessary incentive for proper preservation of heritage buildings connected to the repeal of the rental act control, one initiative of PHT was to offer support to shophouse owners. Another equally important initiative to strengthen the city's tourism through an advanced "mapping out" of the inner city, as well as complying with the rules of the UNESCO listing, was to provide the inner city with historic street name plaques.

The Penang Tourism Action Council officially appointed PHT as consultant for the project on May 27, 2008. The necessity to streamline the activities and put a stronger focus on advocacy in different realms of society (participation in government committees, education for children, deliveries of media statements, heritage alerts, and the mobilisation of public pressure) became obvious. ${ }^{52}$

Most NGOs in Malaysia are proven to be "either collaborators or vehicles of the state" (Cheng, Li, and Ma 2014: 621) as they, contrary to PHT, count on state funding or state co-operation. Penang Apprenticeship Program for Artisans (PAPA) was introduced in 2009, actively supporting immaterial heritage through the financial assistance of artisans and performers, as well as professional training of heritage guides. While advocating sustainable heritage management along with initiatives to preserve and strengthen local traditions, it is highly probable that the main problem for George Town is related to what initially seemed a blessing: tourism. This new challenge has been poignantly addressed by the PHT's chairwoman: "one day we will wake up to find 50 souvenir shops, 500 hotels, but only 5,000 Penang residents left."53

With its explicit multicultural agenda, how can PHT be related to ethnic policies and their influence on Malaysian heritage discourse? To answer this question we have to pay attention to various aspects underscoring the uniqueness of both PHT and Penang. The first is the opposition to the way official heritage discourse is carried out in Melaka, where Chinese heritage is being wilfully neglected. Further, the vital force enabling PHT to mount "resistance to the official criteria and modes of heritage conservation" (Cheng, Li, and Ma 2014: 621) must be seen within the historical framework, in which Penang has enjoyed both a geographical "peripheral grace" as well as a specific economic and educational composition among its inhabitants. The distance from the nation's political centre, often paired with oppositional party rule, has perpetuated specific structures of political activism and localism ever since Malaysia's independence.

\footnotetext{
${ }^{52}$ Heritage alert is an initiative to publicly draw attention to unlawful developments where heritage is being damaged. The alerts can be related to different areas such as: demolition or changes to heritage buildings, illegal land clearing or historical burial sites and memorial monuments.

${ }^{53}$ Brief interview with Khoo Salma in December 2014.
} 
Alongside the modernising trends experimented in Penang, the cultural institutions of Huì and Gōngsī also played a crucial role in the social fabric and even partly substituted the state as provider of charity, public goods, and social order. PHT has thus been shaped by this specific socio-cultural context and can possibly be regarded as intending to "carry on" these embedded traditions, a conclusion that accords with Holst's remark that "although advocacy-oriented NGOs have developed only from the 1970s onward, these organizations build on a long tradition of associations that deals largely with community-related issues in a wider sense such as education, culture, religion, or economic development" (Holst 2012: 187).

What is telling when analysing PHT's agenda in relation to the "ethnic discourse" is that, although many initiatives have been carried out to reinforce the multicultural membership, very little has happened: PHT's membership structure has stayed almost intact since the very beginning, and people of Chinese descent make up for at least ninety-five per cent of the organisation.

How is it possible that an NGO with such a strong commitment and successful dedication to serve and celebrate Penang's multicultural heritage fails to attract people of different descent? ${ }^{54}$ Currently, the non-Chinese members of the NGO also seem to occupy high positions, possibly "alibi positions" as the lack of non-Chinese membership is negatively affecting PHT, which is involuntarily regarded by many locals as "a Chinese NGO."

When comparing the situation with BHT in Semarang, the difference is striking. In Semarang, a patriarchal and completely Chinese-oriented cultural association has transformed into a predominantly female social organisation, with the majority of the members being of Javanese descent. In Penang, an NGO dedicated to global values of concern to all citizens, proves to be incapable of attracting members from "ethnic groups" other than the Chinese. ${ }^{55}$ All attempts to discuss ethnicisation with employees or volunteers of PHT were turned down as the matter was regarded "too sensitive." Even to discuss the role of the heavily state funded George Town World Heritage Incorporation (GTWHI), established in 2009 and equipped with fifteen full-time employees (compared to the meagre staff of two full-time employees in the case of PHT) proved to be unfeasible. The reasons behind the establishment of GTWHI are to a

\footnotetext{
54 That the intents to "reach out" are sincere were witnessed in interactions with Indian and Malay individuals visiting the venues of PHT in December 2014. Statements referring to the desire for a "balanced" membership have often been made, and it is also clear that PHT would benefit from a higher percentage of non-Chinese members as it would better reflect and corroborate the mission of the NGO.

${ }^{55}$ Language is not a barrier. PHT members that use Chinese as the preferred language of communication have only recently entered the organisation, and the working language will be split between English and Malaysian, thus available to all (Interview with PHT volunteer on July 11, 2015).
} 
certain extent questionable as the assigned tasks are very similar to ones already carried out by PHT, which might also be the reason behind the unwillingness among PHT staff and volunteers to touch upon the topic.

PHT can thus be seen as atypical for the general heritage discourse in Malaysia, as the NGO is strongly influenced by Penang's geographical, demographical, and sociopolitical conditions as mentioned above. What is noticeable in the case of PHT might be indicative for the society as a whole: the field of heritage preservation and discourse seems to interest people of Chinese descent to a greatly higher extent than other individuals in the Malaysian society.

\section{Conclusion}

As a consequence of widespread decolonisation in the middle of the twentieth century, many developing countries gained independence. In the process of negotiating the political and social contracts within these new independent polities, ethnic policies gained momentum, which in the case of Indonesia and Malaysia notably affected people of Chinese descent.

In Southeast Asia, the intentions of ethnic policies depended on the prevailing political systems and the economic situations of the new nation states. Other factors such as demographic structures, relationship between the "indigenous" and the "Chinese minority," as well as the nation state's relationship with China also influenced the extent these ethnic policies reinforced assimilation, acculturation, accommodation, or cultural plurality. In Indonesia, policies of assimilation were implemented for more than three decades (1967-2000) with the intention to destroy all forms of Chinese cultural heritage. In Malaysia, instead of introducing explicit anti-Chinese policies, affirmative policies were introduced (1971) that granted special rights to the bumiputera Malays. The consequences of these policies have gradually reduced the people of Chinese descent (along with other non-bumiputera citizens) into "second-class citizens," as access to different benefits such as scholarships, education, trade licenses, and housing are reserved for bumiputera Malays.

The reinforced ethnicisation after Indonesian and Malaysian independence cannot be regarded as a new phenomenon, but ought to be traced back to the colonial era, when the British and the Dutch regimes supported ethnic segregation for their own economic and political benefit. Aspirations to curb Chinese participation in socio-political life and prevent Chinese heritage from prospering have been partly successful in both Indonesia and Malaysia, yet to different extents.

This article was based on the hypothesis that the scope and range of activities carried out by NGOs, which regard themselves as advocates of cultural heritage, could be revealing when seeking an answer to the question whether ethnic policies have 
affected the dynamic dimensions of Chinese cultural heritage in Indonesia and Malaysia.

In the case of Indonesia, the examined NGO provides a rather straightforward answer to this question: ethnic policies under Suharto's rule have led to severe damage of different aspects of Chinese cultural heritage. This is visible in both tangible heritage, as architecture or artefacts with Chinese imprints have been either destroyed or neglected, and intangible heritage, as only a fragment of Semarang's inhabitants speaks Chinese. ${ }^{56}$ Further, the range of activities carried out by the NGO are very limited and predominantly focused on the festivities around the Chinese New Year (Imlek). Although the ethnic policies that targeted Chinese heritage in Indonesia were lifted in 2000, a certain stigma, which impedes a more dynamic stance towards heritage revitalisation and/or preservation, is clearly noticeable.

In the Malaysian case, the NGO in focus is located in Penang, a city with a unique ethno-economic composition, historic trajectory, and geo-political location far away from the bumiputera Malay-dominated heritage discourse, all factors that have helped in preventing the city from state-imposed destruction of Chinese heritage. The Malaysian state has also benefitted greatly in economic terms from the "distinguished capacity of Penang's voluntary sector in narrating and enabling heritage provision" (Cheng, Li, and Ma 2014: 619), resulting in the status as UNESCO World Heritage Site in 2008, as it has created a steady influx of both national and international tourists.

The Malaysian policies affecting heritage can possibly be regarded as pragmatic: the state is inclined to approve if heritage generates revenues. According to Ashworth, Graham, and Tunbridge (2007), Malaysia is an example of a plural society referred to as category core + , which indicates that the society is represented through a consensual core identity to which a number of minority groups are added. ${ }^{57}$ In a core+ society heritage is often a

consequence of ad hoc reactions and adjustments of governments and individuals [...]. It may be used as the instrument for creating and sustaining the leading culture. It can adopt a defensive position whose task is to preserve the integrity of the core, preventing its perceived essential character from being diluted and subsumed by the periphery. Simultaneously, it can be used to

\footnotetext{
${ }^{56}$ A telling observation took place during the Chinese New Year's ceremony in the Chinese Christian Church Gereja ST Franciscus Xaverius (Francis Xaverius' Church) in Pecinan in February 2014. The priest opened the sermon by asking the audience: "Nǐ hăo ma?" (How are you?). However, the priest did not wait for the reply but instead answered himself: "nǐ hěn hăo, xièxie!" (You are fine, thanks!). Apparently, nobody realised the mistake, apart from the priest himself, who, somewhat embarrassed, cleared his voice to correct himself: "wǒ hěn hăo" (I'm fine). There were also other indications of the same kind during the ceremony, which was approximately attended by 400 persons, almost exclusively of Chinese descent.

${ }^{57}$ There are various forms of plural societies, referred to as "integrationist or single-core, melting pot, core+, pillar or salad bowl-rainbow-mosaic" (see Ashworth, Graham, and Tunbridge 2007: 72).
} 
promote the values and norms of the core aiming the peripheral add-ons thus preventing society fragmenting into non-communication cells (Ashworth, Graham, and Tunbridge 2007: 81).

In Malaysia both the Casado Malay-Portuguese and the Peranakan heritage are favoured "as useful 'add-ons' to the Malay core" (Ashworth, Graham, and Tunbridge 2007: 153). Following this strain of thought, Chinese or Peranakan heritage can only be referred to in marginal terms, without any ambition to be of crucial relevance and, therefore, constituting no threat to the Malay national narrative.

In the case of the prosperous city of Penang, the result of more than half a century of ethnic policies has thus not severely affected the Chinese cultural heritage (as the Malaysian state benefits in economic terms from its existence and maintenance), but the whole socio-political landscape is embedded in a "racial discourse": the NGO in this study cannot circumvent the ascription "Chinese," despite all sincere intents to represent all ethnic groups of the nation. The sustained political agenda supporting ethnic policies has created a society with rigid ethnic boundaries, separating Chinese, Malay, and Indian individuals into separate enclaves.

The NGO in focus of this article did manage to implement many of its initiatives to save and protect cultural heritage in the city, but the path has been strenuous and not without suspicion from Malaysian authorities, often combined with more subtle form of surveillance.

\section{ABBREVIATIONS}

$\begin{array}{ll}\text { BAPERKI } & \begin{array}{l}\text { Badan Permusjawaratan Kewarganegaraan Indonesia } \\ \text { BHT }\end{array} \\ \text { BTWHI } & \text { Geon Hian Tong } \\ \text { LHTA } & \text { Living Heritage Treasurers of Penang Awards } \\ \text { NEP } & \text { New Economic Policy } \\ \text { NGO } & \text { Non-Governmental Organisation } \\ \text { NPC } & \text { National Culture Policy } \\ \text { PAPA } & \text { Penang Apprenticeship Program for Artisans } \\ \text { PHT } & \text { Penang Heritage Trust } \\ \text { PKI } & \text { Partai Komunis Indonesia } \\ \text { PRC } & \text { People's Republic of China }\end{array}$

\section{REFERENCES}

Abalahin, Andrew J. 2005. "A Sixth Religion? Confucianism and the Negotiation of IndonesianChinese Identity under the Pancasila State." In Andrew C. Willford and Kenneth M. George, eds., Spirited Politics. Religion and Public Life in Contemporary Southeast Asia. Ithaca: Cornell University Press, pp. 119-142. 
Alkatiri, Zeffry, Vincentia Irmayanti, and Adrianus L. G. Waworuntu. 2015. "The Failure of Indonesian Integration in the Reform Era: A Case of Semarang's Chinese Community." International Journal of Social Science Studies, 3 (2), pp. 61-70.

Anonymous. 1976. 1876-1976 Buku Peringatan H.U.T. ke 100, Rasa Dharma d/h Boen Hian Tong, Semarang [Commemorating hundred years of Rasa Dharma/Boen Hian Tong, 18761976, Semarang].

Ashworth, Gregory J., Brian Graham, and John E. Tunbridge. 2007. Pluralising Pasts: Heritage, Identity and Place in Multicultural Societies. London: Pluto Press.

Atsumi, Saeku. 2003. "The Repeal of Rent Control in Malaysia." Cornell Real Estate Review, 2, pp. 29-38.

Berman, Evan M., ed. 2011. Public Administration in Southeast Asia: Thailand, Philippines, Malaysia, Hong Kong, and Macau. Boca Raton: CRC Press.

Bonacich, Edna. 1973. “A Theory of Middleman Minorities.” American Sociological Review, 38, pp. 583-594.

Cheng, Edmund W., Anthony H. F. Li, and Shu-Yu Ma. 2014. "Resistance, Engagement, and Heritage Conservation by Voluntary Sector: The Case of Penang in Malaysia." Modern Asian Studies, 48, pp. 617-644.

Chin, James. 2011. "History and Context of Public Administration in Malaysia." In Evan M. Berman, ed., Public Administration in Southeast Asia: Thailand, Philippines, Malaysia, Hong Kong, and Macau. Boca Raton: CRC Press, pp. 141-153.

Chirot, Daniel and Anthony Reid, eds. 1997. Essential Outsiders: Chinese and Jews in the Modern Transformation of Southeast Asia and Central Europe. Seattle: University of Washington Press.

Collins, Alan. 2006. "Chinese Educationalists in Malaysia: Defenders of Chinese Identity." Asian Survey, 2 (46), pp. 298-318.

Coppel, Charles A. 2002. Studying Ethnic Chinese in Indonesia. Singapore: Society of Asian Studies.

Coppel, Charles, A. 2013. "Diaspora and Hybridity Peranakan Chinese Culture in Indonesia.” In Chee-Beng Tan, ed., Routledge Handbook of the Chinese Diaspora. London and New York: Routledge, pp. 345-358.

De Bernardi, Jean. 2009. Penang: Rites of Belonging in a Malaysian Chinese Community. Singapore: NUS Press.

Ganesan, N. 2012. "Hindraf's Contribution to Adjust and Progress Social Values within Malaysian Society." Paper presented at the conference "Institutionalized Racism in Malaysia" on January 17. Kuala Lumpur Chinese Assembly Hall.

Graezer Bideau, Florence and Mondher Kilani. 2009. "Chinese Clan Jetties of Penang: How Margins are Becoming Part of a World Cultural Heritage." Chinese Southern Diaspora Studies, 3, pp. 143-166.

Hara, Fujio. 2003. Malayan Chinese and China: Conversion in Identity Consciousness, 19451957. Singapore: Singapore University Press.

Hashim, Harun. 1997. "Of Heritage and Rent-Controlled Buildings.” PHT newsletter, 35/36. Penang Heritage Trust.

Heidhues, Mary Somers. 2003. "Bystanders, Participants, Victims: The Chinese in Java and West Kalimantan 1945-1946." Paper presented at the conference "Changing Regimes and Shifting Loyalties: Identity and Violence in the Early Revolution," on June 25-27. Amsterdam, NIOD.

Holst, Frederik. 2012. Ethnicization and Identity Construction in Malaysia. London: Routledge.

Horowitz, Donald L. 1975. "Ethnic Identity." In Nathan Glazer and Daniel P. Moynihan, eds., Ethnicity: Theory and Experience. Cambridge: Harvard University Press, pp. 111-140. 
Husin, W. H. W. 2012. "Cultural Clash between the Malays and Chinese in Malaysia: An Analysis on the Formation and Implementation of National Cultural Policy." 2012 International Conference on Humanity, History and Society, IPEDR, 34. Singapore: IACSIT Press, pp. 1-6.

Italiaander, Rolf, ed. 1976. Indonesiens verantwortliche Gesellschaft. Erlangen: Verlag der Ev.Luth. Mission.

Ji, Kok Hu. 1997. "Malaysian Chinese Folk Religion: With Special Reference to Weizhen Gong in Kuala Lumpur." In Cheu Hock Tong, ed., Chinese Beliefs and Practices in Southeast Asia: Studies on the Chinese Religion in Malaysia, Singapore and Indonesia. Malaysia: Pelanduk Publications, pp. 103-142.

Khoo, Su Nin. 2007. Streets of George Town Penang: An Illustrated Guide to Penang's City Streets and Historic Attractions. 4th ed. Penang: Areca Books.

Khoo, Salma Nasution. 2010. "The 'Street of Harmony' in the George Town World Heritage Site.” In François Ruegg and Andrea Boscoboinik, eds., From Palermo to Penang / De Palerme à Penang: A Journey into Political Anthropology / Un Itinéraire en Anthropologie Politique. Berlin: LIT Verlag, pp. 283-295.

Küchler, Johannes. 1968. Penang. Kulturlandschaftswandel und ethnisch-soziale Struktur einer Insel Malaysias. Giessen: Wilhelm Schmidt Verlag.

Li, Peter S. and Eva Xiaoling Li. 2013. "The Chinese Overseas Population.” In Chee-Beng Tan, ed., Routledge Handbook of the Chinese Diaspora. London and New York: Routledge, pp. 1528.

Liu, Hong. 2011. China and the Shaping of Indonesia 1949-1965. Singapore: NUS Press in Association with Kyoto University Press.

Muzaffar, Chandra. 2002. Rights, Religion and Reform: Enhancing Human Dignity through Spiritual and Moral Transformation. London and New York: Routledge Curzon.

Panggabean, Samsu Rizal and Benjamin Smith. 2011. "Explaining Anti-Chinese Riots in Late 20th Century Indonesia.” World Development, 39 (2), pp. 231-242.

Purcell, Victor. 1965. The Chinese in Southeast Asia. 2nd ed. Oxford: Oxford University Press.

Shamsul, A. B. and Daud Sity. 2006. "Nation, Ethnicity, and the Contending Discourse in the Malaysian State." In Richard Boyd and Tak-Wing Ngo, eds., State Making in Asia. London and New York: Routledge, pp. 134-143.

Skinner, G. William. 1959. "Overseas Chinese in Southeast Asia." Annals of the American Academy of Political and Social Science, 321, pp. 136-147.

Suryadinata, Leo. 2001. "Chinese Politics in post-Suharto's Indonesia: Beyond the Ethnic Approach?” Asian Survey, 41 (3), pp. 502-524.

Suryadinata, Leo. 2005. Pribumi Indonesians, the Chinese Minority and China: A Study of Perceptions and Politics. Singapore: Times Academic Press.

Suryadinata, Leo. 2013. "Southeast Asian Policies toward the Ethnic Chinese." In Chee-Beng Tan, ed., Routledge Handbook of the Chinese Diaspora. London and New York: Routledge, pp. 274-289.

Szabó, Anna Gabriella. 2015. "Ethnic Policies Toward People of Chinese Descent in Indonesia and Malaysia." M.A. Thesis, University of Vienna, Austria.

Tahir, Ibrahim, ed. 2008. Peranakan Museum A-Z Guide. Singapore: KHL Printing.

Tan, Chee Beng. 2012. "Shantang, Charitable Temples in China, Singapore, and Malaysia." Asian Ethnology, 71 (1), pp. 75-107.

Tan, Chee-Beng, ed. 2013. Routledge Handbook of the Chinese Diaspora. London and New York: Routledge.

Tan, Chee-Beng. 2018. Chinese Religion in Malaysia: Temples and Communities. Boston and Leiden: Brill. 
Tan, Mély, G. 1991. "The Social and Cultural Dimensions of the Role of Ethnic Chinese in Indonesian Society." The Role of the Indonesian Chinese in Shaping Modern Indonesian Life. Special issue of Indonesia. Southeast Asia Program Publications at Cornell University, pp. 113125.

Tan, Sooi Beng. 2008. "Activism in Southeast Asian Ethnomusicology: Empowering Youths to Revitalize Traditions and Bridge Cultural Barriers.” Musicological Annual, 44, pp. 69-84.

Teske, Raymond H. C. and Bardin Nelson H. 1974. "Acculturation and Assimilation: A Clarification." American Ethnologist, 1 (2), pp. 351-367.

Tio, Jongkie. 2013. Semarang City: A Glance into the Past. 2nd ed. Semarang: self-published.

Trustees of Leong San Tong Khoo Kongsi. 2003. Discovery Leong San Tong Khoo Kongsi. 2nd ed. Penang: Viviar Printing.

Walker, Kirsty. 2012. "Intimate Interactions: Eurasian Family Histories in Colonial Penang." Modern Asian Studies, 46 (2), pp. 303-329.

Watson Andaya, Barbara and Leonard Y. Andaya. 2001. A History of Malaysia. 2nd ed. Hampshire: Palgrave.

Wijayanti, Widya, Dyah Wijaya Dewi, Adji Nugroho, and Thomas Nugroho. 2014. Pasar Imlek SEMAWIS CIA GWEE 2565, 27-29 Januari 2014 Wot Gandul Timur - Gang Pinggir, Semarang [New Year Festival - Kopi Semawis traditional market in the lunar year of 2565, January 27-29, 2014, East Wot Gandul Area - Gang Pinggir, Semarang]. Semarang: Certakan Pertama.

Willmott, Donald. 1960. The Chinese of Semarang: A Changing Minority Community in Indonesia. New York: Cornell University Press.

Winzeler, Robert, L. 2011. The Peoples of Southeast Asia Today: Ethnography, Ethnology, and Change in a Complex Region. Maryland: AltaMira Press.

Zainal, Aznam Yusof. 2006. "Policy Brief 13." Overseas Development Institute. Online: http://www.odi.org/sites/odi.org.uk/files/odi-assets/publications-opinion-files/4078.pdf (accessed: December 17, 2020). 